
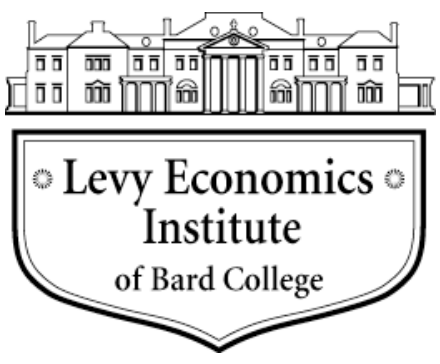

Working Paper No. 848

\title{
Is Monetary Financing Inflationary? A Case Study of the Canadian Economy, 1935-75
}

by

\author{
Josh Ryan-Collins* \\ Associate Director \\ Economy and Finance Program \\ The New Economics Foundation
}

October 2015

* Visiting Fellow, University of Southampton, Centre for Banking, Finance and Sustainable Development, Southampton Business School, Building 2, Southampton SO17 1TR, jjrc1c11@soton.ac.uk; Associate Director, Economy and Finance Programme, The New Economics Foundation (NEF), 10 Salamanca Place, London SE1 7HB, josh.ryan-collins@neweconomics.org.

The Levy Economics Institute Working Paper Collection presents research in progress by Levy Institute scholars and conference participants. The purpose of the series is to disseminate ideas to and elicit comments from academics and professionals.

Levy Economics Institute of Bard College, founded in 1986, is a nonprofit, nonpartisan, independently funded research organization devoted to public service. Through scholarship and economic research it generates viable, effective public policy responses to important economic problems that profoundly affect the quality of life in the United States and abroad.

Levy Economics Institute P.O. Box 5000

Annandale-on-Hudson, NY 12504-5000

http://www.levyinstitute.org

Copyright (C) Levy Economics Institute 2015 All rights reserved 


\begin{abstract}
Historically high levels of private and public debt coupled with already very low short-term interest rates appear to limit the options for stimulative monetary policy in many advanced economies today. One option that has not yet been considered is monetary financing by central banks to boost demand and/or relieve debt burdens. We find little empirical evidence to support the standard objection to such policies: that they will lead to uncontrollable inflation. Theoretical models of inflationary monetary financing rest upon inaccurate conceptions of the modern endogenous money creation process. This paper presents a counter-example in the activities of the Bank of Canada during the period 1935-75, when, working with the government, it engaged in significant direct or indirect monetary financing to support fiscal expansion, economic growth, and industrialization. An institutional case study of the period, complemented by a general-to-specific econometric analysis, finds no support for a relationship between monetary financing and inflation. The findings lend support to recent calls for explicit monetary financing to boost highly indebted economies and a more general rethink of the dominant New Macroeconomic Consensus policy framework that prohibits monetary financing.
\end{abstract}

Keywords: Monetary Policy; Monetary Financing; Inflation; Central Bank Independence; Fiscal Policy; Debt; Credit Creation

JEL Classifications: B22, B25, E02, E12, E14, E31, E42, E51, E52, E58, E63, N12, $\mathrm{N} 22, \mathrm{O} 43$ 


\section{INTRODUCTION}

What is the appropriate role for monetary policy in economies - such as today's developed nations - with low or stagnant growth and high levels of private and public debt, much of it externally owned? ${ }^{1}$ There is limited room for maneuver in regard to interest rates which have been at record lows in most advanced economies since 2008. To try and bring down medium and longer term rates, the major central banks embarked on "quantitative easing" (QE) or large-scale asset purchases, mainly of government debt (e.g., Joyce et al. 2012). Despite these unorthodox policies, recovery has been slower in most advanced economies in relation to past recessions, leading some to talk of a "secular stagnation" (Summers 2013). Concerns have also been raised that $\mathrm{QE}$ policies and associated low interest rates may lead to a further growth in the kind of unsustainable private debt and/or asset price booms that helped cause the 2008 crisis (Mian and Sufi 2010; Stein 2013; BIS 2014). This may be related to the finding reported in recent empirical studies that commercial banks, which monopolize the creation of credit and money in economies, are shifting their lending towards existing assets (in particular real estate) over non-financial business lending (Jordà et al. 2014; Bezemer et al. 2014).

One alternative that has been proposed by a number of economists in the postcrisis era is for central banks to engage in "monetary financing" (Benes and Kumhof 2012; Mcculley and Poszar 2013; Turner 2013; Wolf 2013; Dyson and Jackson 2013; Muellbauer 2014). This involves the creation of central bank money on a permanent basis ${ }^{2}$ to either finance government deficits or to provide an injection of funding to citizens - so-called "helicopter money." Such a policy was also advocated by former Federal Reserve Governor Ben Bernanke (2003) as a means of boosting nominal GDP in Japan in the early 2000s. Monetary financing can also involve requiring private banks to buy and hold government debt or lend directly to governments. This policy is recognized as a tool used by governments to reduce debt-to-GDP ratios in the post-Second World War period, particularly when combined with higher inflation levels; it has been described as "financial repression" (Shaw 1973; Mckinnon 1973).

\footnotetext{
${ }^{1}$ Rheinhart and Rogoff $(2013,6)$ examine gross public debt-to-GDP ratios going back to 1800 and find that the current level of central government debt in advanced economies is approaching a two-century high-water mark. They also find that gross total (public plus private) external debt as a percentage of GDP to be on average $260 \%$ of GDP in 22 advanced countries, compared to just $25 \%$ in 1970.

${ }^{2}$ By making the monetization permanent (i.e., committing not to sterilize the effects via open-market sales of bond sales at a later date), the "Ricardian equivalence" problem that consumers will increase their savings assuming a later increase taxes to fund the resulting deficit may be avoided; see for example Reichlin et al. (2013) for a discussion.
} 
The policy of large-scale monetary financing has historical antecedents in both monetarist and Keynesian theoretical traditions. The term helicopter money was proposed by Milton Friedman (1948) whilst early Chicago School economists writing during the Great Depression argued that money creation should only be conducted by governments/central banks via a "full-reserve banking" policy (Fisher 1936; Douglas et al. 1939). However, there are also parallels with the "Functional Finance" approach of Lerner (1943), a variant of which has been recently revived under the label of "Modern Monetary Theory" (Wray 1998, 2012), itself strongly influenced by Keynes. The latter approach emphasizes that since the ultimate source of monetary authority lies with the state/central bank in a sovereign fiat-currency regime, it does not make sense for governments to "borrow" via bond financing; rather there should be no limits on a state's ability to fund socially agreed upon objectives, such as full employment, via sovereign money creation.

From one perspective, the current QE programs (now totaling around \$11 trillion [Investment Investment Watch Blog 2015]), which mainly involved the purchase of government debt, can be seen as an implicit form of monetary financing if it is accepted that central banks are unlikely to ever completely unwind their purchases. This has certainly been the case in past episodes of crisis-induced balance sheet expansion. ${ }^{3}$ Given such central banks are owned by the same governments that issue the purchased debt, no net public liability exists, whilst the interest expense, as a profit of the central bank, returns to the government (Turner 2014; Johnston and Pugh 2014). ${ }^{4}$ Sbrancia (2011) and Reinhart and Sbrancia (2011) have argued that current $\mathrm{QE}$ policies should be viewed as a form of financial repression that is being conducted to try and reduce the public debt that resulted from the 2007-08 financial crisis.

Monetary financing has, however, come to be seen as dangerously inflationary in both the public perception and in mainstream economic theory. Up until the 2008 crisis, the policy had virtually disappeared in advanced economies, although it is still widely used in emerging markets; see, for example, Catao and Terrones (2005). This was due to the dominance of "New Macroeconomic Consensus" policies focused on inflation targeting as the key objective of monetary policy and the view that the operational independence of central banks was key to achieving credibility. Such independence would not be possible under conditions where governments could demand that central banks monetize a portion of government deficitshence these were prohibited. But viewed in the broader sweep of the last 300 years since the

\footnotetext{
${ }^{3}$ Ferguson et al. (2014) examine central bank balance sheets in 12 countries since 1900 and find that, following major expansions following crises, "central banks have rarely reduced the size of their balance sheets in nominal terms" and that "reductions are predominantly achieved relative to output by holding nominal positions stable for long periods."

${ }^{4}$ This type of transfer of seigniorage profits from the central bank has been standard practice in the US, Japan, and Canada for some time. The UK adopted the same policy in November 2012.
} 
emergence of modern central banking, such policies appear exceptional (Epstein 2006; Cobham 2012). From a political economy perspective, some have argued that, rather than becoming truly "independent" since the 1990s, central banks have rather supported one particular sector - the (international) financial sector-over the state, industry, and production (Epstein 1992; Posen 1995, 1998; Ingham 2004). Others have argued that central banks themselves encouraged "independence" as a means of increasing their own institutional power base (Goodman 1991; Werner 2003; Forder 2005).

The period from the 1930s through the 1970s offers some interesting and little-studied examples of monetary activism by governments and central banks to support economies in a situation, much like today, with very low interest rates and very high debt-to-GDP ratios. ${ }^{5}$ In this period central banks financed expansionary government spending and capital investment focused on economic development and full employment. A political economy perspective is useful in understanding the historical dynamics involved. In countries that already had central banks, the deflation and unemployment of the Great Depression led to a re-think of monetary authorities' role vis-à-vis government and the financial sector. In addition, in a number former colonies, such as Canada, New Zealand, Australia, and India, new central banks were set up to help establish national monetary sovereignty from Great Britain. ${ }^{6}$ Their origins thus do not fit the classic explanation of central bank emergence as a means for more support for sovereign war efforts, the more efficient running of the financial system, or supporting existing private banking interests via providing the "lender of last resort" function (Goodhart 1988; Capie et al. 1994).

These origins in the desire for greater monetary sovereignty and public job creation gave encouragement to instances of monetary financing. These included direct financing of government debt by central banks and requiring private banks to purchase and hold government debt. Central banks in these states worked collaboratively with governments and, as will be shown with the example of Canada, played an important role in reflating their economies following the Depression and financing the war effort, as well as postwar reconstruction and industrialization more generally, and reducing public debt levels.

Analyzing monetary policy in the period 1930-70 poses empirical and theoretical challenges. There is a lack of reliable macroeconomic data and the existence of fixed exchange rates and a range of other controls on domestic and international capital markets make comparison with today's more financially liberalized and globalized economies difficult. In addition, the Great

${ }^{6}$ On New Zealand, see Sinclair (1976) and Hawke (1973); on Australia, see Brown (2013, ch15). 
Depression and Second World War are massive economic dislocations that affected different countries in quite different ways, making comparative generalizations across the period difficult.

To partially address these limitations, an institutional case-study approach is taken to the only major country that operated under a flexible exchange rate through the majority of the period 1945-75: Canada. By the end of 1951, Canada had also eliminated all remaining controls on foreign exchange transactions and most, if not all, controls on foreign investment inflows (Thiessen 2001, 5). While its close connection to the US clearly makes Canada a somewhat unique case, to some degree at least it can be seen as having parallels to a modern-day, small, open economy. Canada also makes a topical case since its central bank is currently being sued for failing to fulfill its mandate to provide interest-free loans for public projects undertaken by federal, provincial, and city governments. ${ }^{7}$ To complement the case study analysis, a generalto-specific (GETS) empirical econometric model of Canadian inflation is presented, using a newly collected historical dataset going back to the 1950s, to examine the extent to which the persistent monetization of debt contributed to inflationary pressures.

The paper is laid out as follows. Section 2 reviews the literature on government money creation, its relationship to inflation, and the development of the current policy framework, which essentially prohibits monetary financing. Section 3 is the institutional case study. Section 4 presents the empirical model of Canadian inflation and section 5 concludes.

\section{HISTORICAL AND THEORETICAL CONTEXT}

\subsection{The State Origins of Money and the Turn to Commercial-Bank Money}

Historical, anthropological, and numismatic evidence points to the origins of money in the role of the state or related authority and its ability to determine the unit of account function of money via the imposition of liabilities on citizens (Knapp 1905; Innes 1913; Grierson 1978). This "Chartalist" explanation of money lies in contrast with the "Metallist" conception that remains more prevalent in the economics literature, where money emerges as a more efficient private medium of exchange than barter (Jevons 1875; Menger 1892). In fact the historical evidence suggests barter was virtually non-existent in primitive and ancient societies (Humphrey 1985; Wray 1998; Goodhart 1998; Ingham 2004; Graeber 2011). Rather, the first commercial transactions took place on the basis of credit clearing systems whose

\footnotetext{
${ }^{7}$ The case is being pursued by the constitutional lawyer Rocco Galati on behalf of the Committee on Monetary Reform (COMER) campaign group. See Whittington (2015) and www.comer.org for more information.
} 
denomination was typically in agricultural commodities, including cattle, weighted grain, and tools (Grierson 1978).

Prior to the invention of modern banking at the end of the seventeenth century, many states used simple accounting techniques, such as tally sticks, minted coins, or printed paper money to fund their activities and ensured their widespread adoption through taxation (Knapp 1905; Grierson 1978; Ingham 2004; Graeber 2011). In Britain, for example, for hundreds of years prior to the establishment of the Bank of England's monopoly on the right to create banknotes in 1844, the state and kings issued a mixture of gold and silver coinage or recorded credit and debts in the form of notches on hazelwood sticks-so-called tally sticks (Astle 1997;

Richards 1929, 58-59). Although historical data is somewhat limited, government-created monetary regimes in the UK and the US up to the late seventeenth century seem to have been reasonably stable (Benes and Kumhof 2012, 14-15; Zarlenga 2004). The governments of Germany, Japan, and the US also issued significant amounts of government money during the eighteenth and nineteenth centuries (Zarlenga 2004; Werner 2005; Benes and Kumhof 2012; Brown 2013).

The phenomenon of private banks effectively monopolizing credit creation and allocationvia fractional reserve banking and interest bearing debt-is relatively recent. ${ }^{8}$ In the UK, for example, from 1870 to about 1970, the central bank was responsible for issuing between $18 \%$ and $21 \%$ of the total money supply in the form of interest-free bank notes and coins (Capie and Webber 1985). Since the 1970s, the emergence of electronic forms of payment has led to a reduction in the use of notes and coins and now only around 3\% of money in circulation is created by the central bank with the remainder being commercial bank liabilities in the form of customer deposits. ${ }^{9}$ Such liabilities are created when banks extend credit, buy financial assets, or fulfill overdraft requests, creating new assets (Ryan-Collins et al. 2011, 56-57; Mcleay et al. 2014). Similar ratios of currency to bank deposit money can be found in most advanced economies, whilst in developing countries, closer to $10 \%$ of circulating money is in the form of currency (BIS 2009, 106)

\footnotetext{
${ }^{8}$ Fractional reserve banking itself has a much longer history. The earliest records of modern European banking, involving widely circulating promissory notes and fractional reserves, dates back to the Medicis of the sixteenth century and became prominent in Britain in the seventeenth century.

${ }^{9}$ In a recent "Quarterly Bulletin" publication, the Bank of England states: "Of the two types of broad money, bank deposits make up the vast majority— $-97 \%$ of the amount currently in circulation. And in the modern economy, those bank deposits are mostly created by commercial banks themselves. (Emphasis in original) (Mcleay et al. 2014, 2).
} 


\subsection{Inflation and Monetary Financing-A Short History}

Why then has the government (or central banks) creating money come to be viewed as inflationary? One explanation is that many of the modern examples of large-scale direct government money creation were for the purposes of raising funds to fight wars. Wartime typically involves very high levels of inflation as production of standard goods and services is slowed and productivity levels drop at the same time as a massive increase in the money supply, which is required to fund the destructive activities of war (Pigou 1941; Davies 2002, 646-48). ${ }^{10}$ Such inflation often persists in the postwar period when resources return to productive use, as governments rarely choose to reduce the money supply.

A popular US example used to justify criticism of government-created money is the "Continentals" that were used to raise funds to fight the War of Independence against the British and fell to one-thousandth of their nominal value by the end of the war (Davies 2002, 647; Lester 1938, 3). In Europe, the stigma associated with government money is perhaps stronger, with examples including the assignats of the French Revolution, the post-WWI hyperinflation in Germany and Austria, and the world's largest ever hyperinflation in Hungary in 1946 (Hanke and Kwok 2009). In the UK, the First World War and its aftermath saw the first and only experiment in government-issued paper money since the medieval tally sticks - the Treasury issuance of "Bradbury Bills" (Higgins 1949)—but also very high levels of inflation.

Public and political concerns about the inflationary consequences of government money creation were not complemented in economic thinking, however, until the monetarist "counterrevolution" of the 1970s and 1980s. Keynes (1933, 23), for example, keen for Depression-era governments to boost demand through direct money creation ("loanexpenditure"), rued that "hitherto war has been the only object of government loanexpenditure on a large scale which governments have considered respectable." Lerner (1943) argued for a "functional finance" whereby a sovereign state with a fiat currency should always create sufficient money to support full employment and use taxation and borrowing, not as a means for raising funds, but for controlling inflation by withdrawing money from firms and households.

\footnotetext{
${ }^{10}$ Pigou (1941) argued there are two "types" of inflation associated with war: 1) wage inflation driven by reduced yield of goods per given quantity of resources engaged in producing them accompanied by an increase in the money supply; and 2) deficit inflation, whereby governments are unable to fund the necessary increase in the money supply through borrowing from citizens - which would reduce money income and wages - and instead creates new money through taking loans from the banking sector (monetary financing).
} 
Even amongst pro-free market economists, it was widely accepted that monetary authorities had two valid options when it came to funding fiscal deficits: bond financing or money financing via central bank or private bank purchase of government debt (monetization). A number of early Chicago School economists including Irving Fisher (1936), (a younger) Milton Friedman (1948), and Henry Simons (1951 [1948]) argued that monetary financing of government deficits would create greater stability than bond financing. The so-called Chicago Plan, written after the Great Depression by Fisher and a number of other Chicago School economists (Douglas et al. 1939) argued that private bank credit creation via fractional reserves was inherently unstable, damaging to industry, and should be outlawed via the imposition of a $100 \%$ reserve ratio - i.e., a return to a public monopoly on money creation.

These proposals were not taken up by governments, however. ${ }^{11}$ The period between the Great Depression and the 1970s saw the survival of private sector money creation but it was subjected to significant formal and informal regulatory controls and complemented by both direct and indirect forms of monetary financing, explored further in sections 3 and 4.

Keynesian "fiscal dominance" was a result not just of the fixed-exchange rate regime but also the fact that government spending was the most significant contributor to aggregate demand in many countries (Cobham 2012, 730). This was enabled by highly accommodating debtmanagement policies by central banks. Indeed, central banks were often subordinated to ministries of finance and had a wide range of goals aside from price and financial stability, including the maintenance of historically low interest rates on government debt and bank debt and the maintenance of exchange-rate parities (Epstein 2006; Cobham 2012, 730).

The Keynesian "Golden Age" came to an abrupt end in the 1970s following the collapse of the Bretton Woods system of fixed exchange rates and the OPEC oil shocks. Explanations for the "great inflations" of the 1970s remain contested today but at the time they were associated with excessively lax monetary policies and fiscal profligacy rather than the exogenous shocks of the oil crises, the collapse of Bretton Woods, and the resulting volatility in international capital flows. Monetarism reemerged, building on new empirical evidence linking the money supply to inflation (Friedman and Schwartz 1963). Friedman (1962) argued that governments were prone to generating excessive inflation by manipulating monetary policy as part of the "political business cycle" (see also Nordhaus 1975) and proposed fixing a target rate of growth for monetary expansion. It was an attractive theory for conservative politicians such

\footnotetext{
${ }^{11}$ The Chicago Plan was considered seriously by President Roosevelt during debates over the New Deal banking reform acts and perhaps helped to establish the separation of investment and retail banking activities (Phillips 1994).
} 
as Margaret Thatcher and Ronald Reagan, determined to link inflation to the failure of the Keynesian policies of incumbent governments (Johnson 1971; Tobin 1981).

The academic sphere also saw the emergence of neoclassical models of supply-demand equilibrium, grounded in microfoundations with agents with rational expectations, perfect foresight, and the long-run "neutrality" of money (Lucas 1972; Phelps 1973; Sargent and Wallace 1975). In such models, it is assumed that government expenditure must be financed either by taxes, by borrowing from the private sector (bond-financing) which increases the public deficit, or via money creation by the central bank which increases the money supply when it purchases government bonds. ${ }^{12}$ When deficits are bond financed, it is assumed that the government competes with the private sector for limited funds and as a consequence interest rates are pushed up. Higher borrowing costs discourage investment and economic activity slows down - the so-called crowding-out effect. When deficits are financed by money creation (or "printing money"), it is assumed that all money is created by the central bank so that the change in the money supply is equal to the change in the monetary base. ${ }^{13}$

Under the assumption of rational expectations, budget deficits financed by money creation could lead to prolonged high inflation episodes and eventually hyperinflation as rational agents would keep reducing their real money balances in favor of non-monetary assets with higher yields, such as government bonds. This would increase the velocity of money, meaning ever-more inflationary financing would be required (e.g., Cagan 1956; Kiguel 1989; Dornbusch 1992). Even with bond financing, neo-classical models argued that as deficits became larger, the amount of interest required to service an increasing public debt would eventually become unsustainable and central banks would then have no option but to monetize the debt (Sargent and Wallace 1981). Indeed, even before any monetization took place, if budget deficits had been persistent and large, agents would begin to expect future monetization and reduce their money balances accordingly, thereby increasing the velocity of money and fulfilling the inflationary expectation. Governments thus face a trade-off between future and present monetization and persistent budget deficits will almost always lead to inflation (Edwards and Tabellini 1991).

\footnotetext{
${ }^{12}$ Many models do not distinguish between governments and central banks, assuming the latter is part of the former.

${ }^{13}$ See Seccareccia and Sood (2000) for a formal presentation of this argument.
} 


\subsection{Central Bank Independence (CBI) as a Solution to Inflation}

These dynamics were theorized as creating a "time inconsistency" problem in the monetary policy sphere (Kydland and Prescott 1977). Since there are benefits to bursts of "surprise" low-level inflation, which tend to increase economic activity and reduce unemployment in the short run, politically influenced central banks will be prone to short-term monetary easing at certain times in the electoral cycle. Agents with rational expectations will begin to adjust the anticipated inflation in to their pricing decisions and labor contracts. The only way monetary expansion can be effective under such circumstance is for it to exceed such expectations, resulting in a positive feedback of ever higher expected and actual inflation with resulting welfare costs (Barro and Gordon 1983b). ${ }^{14}$ Optimal monetary policy is therefore better obtained via the imposition of publicly announced rules - which may be determined in consultation with governments but last at least the length of the electoral cycle — but central banks should be operationally independent to pursue such rules as they wish (Walsh 1995).

These theories began to gain traction in the late 1980s following the publication of a number of empirical papers showing a negative correlation between indices of $\mathrm{CBI}$ and inflation, with prohibition or restrictions on central bank financing of government debt included as one of the indices of CBI (Alesina 1988; Grilli et al. 1991; Cukierman et al. 1992; Alesina and Summers 1993). In addition, the repeated inflationary episodes of the 1980s and 1990s in South America (Sachs 1986), Eastern Europe, and Russia were strongly associated with high budget deficits.

In advanced economies since the 1990s, CBI and inflation targeting - with a heavy emphasis on expectations - have become the primary focus of monetary policy above and beyond other macroeconomic objectives (Woodford 1995; Bernanke and Mishkin 1997). The New Macroeconomic Consensus (NMC) approach has three key elements: ${ }^{15} 1$ ) that the main task of the central bank should be a focus on price stability and the central bank should publicly commit to an "inflation target," normally around a (historically low) rate of $1-3 \% ; 2$ ) to achieve this, the central bank should be operationally and institutionally independent of government or ministries of finance, including being free of any obligation to lend to governments or buy government securities; and 3) that indirect methods of monetary policy (in particular adjustments to interest rates) as opposed to more direct methods of deficit or monetary financing, credit controls, or guidance are appropriate (Bernanke and Mishkin

\footnotetext{
${ }^{14}$ In such theories, it is usually assumed that inflation has no permanent effect on real outcomes, i.e., that there is a vertical long-run Phillips curve and non-accelerating inflation rate of unemployment (NAIRU) (Friedman 1968; Phelps 1973; Gordon 1997).

${ }^{15}$ This definition draws on Arestis and Sawyer (2008). See that article for a detailed critical account of the NMC framework.
} 
1997; Blinder 1999; Epstein 2006; Arestis and Sawyer 2008). Inherent in such an approach is a clear separation of monetary and fiscal policy.

The NMC policies have been institutionally embedded via constitutional and operational changes to the roles of central banks vis-à-vis governments. In Europe, the Treaty of Maastricht, signed in 1992, put in place the prohibition of the direct financing of government spending by any EU member state's central bank. This includes any overdraft or credit facility and the direct purchase of any debt instrument (i.e., gilts, treasury bonds). The policy applies to all EU members, even those, like the UK, outside of the eurozone. ${ }^{16}$ By 2008 , inflation targeting had been adopted by 24 central banks and many more, including those in developing countries, were expressing an interest (Epstein and Yeldan 2008).

While the financial crisis of 2007-08 has led a few central banks (most notably the Bank of England) to significantly boost their macroprudential role and monitor more closely asset prices, the strong focus on consumer price inflation and CBI (and relatedly prohibition of monetary financing) has, by and large, remained unchanged. In a postcrisis review of central bank governance by the Bank of International Settlements (BIS), an organization jointly founded by major central banks, states that:

An important potential channel for an inflationary monetary expansion is central bank financing of budget deficits. Much of the inflationary risk is removed if central bank loans to the government are made at full market rates, particularly when those rates are influenced by the sterilisation operations used to offset the monetary impact. (BIS 2009, 67)

\subsection{Critiques of the NMC and CBI Frameworks}

The NMC/CBI position has been criticized from a range of perspectives: empirical, theoretical, and methodological. Empirically, both panel (Seccareccia and Sood 2000; Catao and Terrones 2005; Lin and Chu 2013) and single-country time series (King and Plosser 1985; Protopapadakis and Siegel 1987; Barnhart and Darrat 1988) studies from a wide variety of countries, historical periods, and different inflation rates fail to find a statistically significant connection between fiscal deficits and inflation, regardless of whether deficits are "funded" via private sector bond purchases or central bank monetization. The CBI indices themselves have been criticized for being overly selective by focusing on the period 1970-90, characterized by a number of inflationary shocks that may have had non-monetary causes,

\footnotetext{
${ }^{16}$ Consolidated Version of the Treaty on the Functioning of the EU. Available at: http://eurlex.europa.eu/LexUriServ/LexUriServ.do?uri=OJ:C:2008:115:0047:0199:EN:PDF [accessed June 14, 2011].
} 
including the OPEC crises of the 1970s and relatedly, balance of payment crises related to the recycling of loans and buildup of third world debts in the 1980s (Hervey 1990, 466; Frieden 2006, 364; Klomp and De Haan 2010). Studies that have included more recent data tend not to find a clear correlation between CBI and inflation (Crowe and Meade 2007).

With regard to hyperinflations, the most comprehensive study available of all 56 recorded cases is that of Hanke and Krus (2012). ${ }^{17}$ The authors report that the vast majority occurred either during or after major wars or other exogenous shocks: "Hyperinflation is an economic malady that arises under extreme conditions: war, political mismanagement, and the transition from a command to market-based economy - to name a few" (Hanke and Krus 2012, 12). Only two of the 56 examples, Peru (1990) and the Weimar Republic (1922-23), can be viewed as occurring under stable democracies (Salmon 2012). With regard to Weimar, there were extraordinary pressures on the country due to the requirement to repay its debts in foreign-denominated currency whilst also opening up its capital markets to damaging speculation (Keynes 1920; Schacht and Butler 1927). In both the US Continentals and French assignat examples mentioned in section 2.2, there were major counterfeiting operations by enemy states during the respective wars (Levasseur 1894; Newman 1958).

The "political inflation" explanations of the developing world (in particular Latin America) inflations of the 1980s have also been called in to question. Rather than a demand-pull explanation caused by monetary financing of increasing government deficits, a number of scholars have emphasized structuralist explanations resulting from the concentrated structure of land ownership and balance-of-payments constraints these regions experienced as their economies developed (see Vernengo [2006, 482-85] and the references therein). Under these approaches, industrialization leads to a reduction in agricultural produce and a shift towards imported capital goods, creating supply-side constraints. This can lead to an increase in food prices (Cardoso 1981) and a resultant reduction in real wages, which may in turn lead to pressures to increase wages above the indexation norm and wage-price spirals.

Even if the existence of a correlation between CBI and low inflation is accepted, this does not imply causation. A number of studies suggest that $\mathrm{CBI}$ is more an effect of low inflation preferences than a cause (De Haan and Van't Hag 1995; Acemoglu et al. 2008; Mann 2010); some studies emphasize the intensity of public expectations to fight inflation (Hayo 1998) or the strength of political forces demanding low inflation (Posen 1998) as causal factors. Other

\footnotetext{
${ }^{17}$ The authors use Cagan's (1956) widely accepted definition of hyperinflation as a price-level increase of at least $50 \%$ per month. When the monthly inflation rate drops below $50 \%$ and stays there for at least one year, the episode is said to end.
} 
scholars have argued that the (low) inflation targeting regime that spread rapidly across the world in the 1990s was a result of the increased power of the financial sector to assert its (creditor) interests over those of households and industry (debtors), since an increase in inflation redistributes real income from creditors to debtors (Bowles and White 1994; Epstein 1992; Ingham 2004; Posen 1995). Such a view is supported by the fact that there is little empirical evidence that moderate inflation - even at 5\% - actually impedes growth (Wray 2007; Epstein and Yeldan 2008). A recently published IMF working paper based on a new database of central bank laws in 150 countries found the expected negative correlation between central bank lending to government and inflation but also a positive correlation between central bank lending to government and real GDP growth in developing countries (and, unsurprisingly, inflation and real GDP growth in such countries) (Jácome et al. 2012, 17). This suggests there is a trade-off between low inflation and growth.

From a theoretical perspective, there are problems with the $\mathrm{NMC} / \mathrm{CBI}$ focus on money rather than credit. The "credit theory of money" approach, which builds on the Chartalist origins of money outlined in section 2.1, argues that the quantity of money (mainly in the form of bank liabilities or deposits) in an economy appears residually as an accounting by-product of the credit flows created by either central banks or private banks (Werner 1997; Parguez and Seccareccia 2000; Graziani 2003). Given that modern credit creation is dominated by commercial banks, it is the quantity of new credit demanded and created by such banks and its allocation in to the economy, and resulting impact on resource allocation that is a key determinant of macroeconomic dynamics, including consumer and asset prices.

One reason less attention may have been paid to the credit creation decisions of private banks is because of the assumption in New Keynesian/NMC models that: 1) the majority of lending by banks goes to non-financial firms; and 2) that (independent) central banks are able to influence such credit flows via adjustments to the short-term interest such that the economy is able to return to an equilibrium or "natural" rate of interest at which point the market clears (Wicksell 1936 [1898]; Barro and Gordon 1983a). ${ }^{18}$ Both of these assumptions are questionable. It has become clear that modern banks in advanced economies actually lend considerably more against existing assets, mainly real estate, than they to do non-financial firms (Jordà et al. 2014; Bezemer et al. 2014). Secondly, there is little evidence of a correlation between the quantity of base money or "loanable funds," or the short-term interest rate ("bankrate") that banks base their interbank lending rate on, and the quantity of credit created by the banking sector. The "money multiplier" seems to have broken down if, indeed,

\footnotetext{
${ }^{18}$ See Pilkington (2014) for a recent critique of the natural rate hypothesis.
} 
it ever existed (Goodhart 2009; Carpenter and Demiralp 2012). As central banks have dropped demands for compulsory reserve or liquidity ratios over the past thirty years, increasingly it is accepted that central banks main role is to accommodate the demand for reserves by the banking system via ensuring there is sufficient liquidity in the systemdescribed by post-Keynesian economists as "endogenous money"19 (Kaldor 1982; Moore 1988; see Howells 2006 for empirical evidence).

Examining monetary aggregates in relation to inflation is also empirically challenging because it is not entirely clear what the best aggregates to measure are. Indeed, this was a central difficulty for monetarist policies. Meanwhile assuming that government or central bank money creation will be inherently inflationary whilst ignoring the impact of private bank credit creation makes little sense unless assumptions about the efficiency of market (i.e., commercial bank) credit allocation over monetary financing are brought in to the argument. In the light of the 2008 financial crisis, when excessive bank credit creation, in particular for mortgages, was a key cause of the crisis and resulting recession, such assumptions would seem problematic.

Relatedly, the measure of inflation that is used in most of the studies supporting CBI is consumer-price inflation rather than asset-price inflation. The neglect of asset-price inflation by monetary authorities is now widely recognized as a mistake, including by central bank staff themselves (Aikman et al. 2014). A number of empirical studies show a very strong relationship between inflated asset prices and financial crises (Cecchetti 2008; Hume and Sentance 2009; Schularick and Taylor 2009).

In summary, the relationship between the state and money creation has changed radically over the past 400 years. Only in the past few decades have we seen the establishment of a consensus around the need to restrict public monetary financing and debt monetization to a negligible level in favor of a private sector monopoly regulated by an independent central bank that, for the most part, restricts its activities to inflation targeting via adjustments to short-term interest rates. Empirical support for such an approach is limited and the theoretical basis for such policies is flawed. As mentioned in the introduction, such arrangements have come under scrutiny following the financial crisis of 2007-08. QE policies-which clearly involve the creation of central bank money on a vast scale — have not led to the kind inflation such theories predict and raise questions about CBI because of the implicit subsidization of

\footnotetext{
${ }^{19}$ See Chick (1996) for a useful discussion of the evolution of the banking system in the UK from one where reserves did actually constrain lending to a system where the central bank must accommodate the demand for reserves from commercial banks to maintain the policy rate of interest.
} 
government debt involved. Given these findings, what can we learn from a more in-depth examination of the period 1930-70 when a different set of policies, much less concerned with the inflationary effects of government or central bank money creation, were commonplace?

\section{A CASE STUDY OF NON-INFLATIONARY MONETARY FINANCING: THE CANADIAN CENTRAL BANK, 1935-75}

The activities of the Canadian central bank from the period of its inception in 1935 to the early 1970s constitute an example of how a central bank, working closely with the state, used indirect and direct monetary financing policies to support industrial development, debt management, and macroeconomic goals that go significantly beyond financial stability and price stability. As shown in figure 1, between $20-25 \%$ of Canadian public debt was financed and held by the central bank and government from the end of World War II up to the early 1980s but inflation was below 5\% right up until the early 1970s, casting doubt on the NMC and CBI hypotheses. We test this thesis empirically in section 4 but in this section elaborate on the historical and institutional dynamics that lead Canada to use monetary financing as a key plank in its economic policy during the period.

The Bank of Canada is a pertinent case to investigate when looking at the monetary financing-inflation hypothesis for a number of reasons. First, as explained below, its origins lay in domestic political pressures following the Great Depression, so from the outset it had a strong mandate to support the wider the economy and public interest, rather than as a body supporting domestic or international financial interests. ${ }^{20}$ Second, Canada was almost unique at the time in have a floating exchange rate for the majority of the 1951-75 period and few other capital controls, making its monetary policy choices more amenable to comparison to modern economies. Whilst Canada was of course heavily influenced economically by its neighbor, the US, it had a very different banking and political system, heavily influenced by European and particularly British traditions (Bordo et al. 1996; Calomiris and Haber 2014, 153-329). In comparison to other potential examples of monetary financing during the period, for example Japan and New Zealand, the period involved is considerably longer and data availability and historical records of higher quality.

\footnotetext{
${ }^{20}$ See Goodhart (1988) for a classic account of the evolution of central banks as institutions serving the interests of commercial banks via the provision of "lender of last resort" functions.
} 
Figure 1: Monetary financing and inflation in Canada, 1958-2012

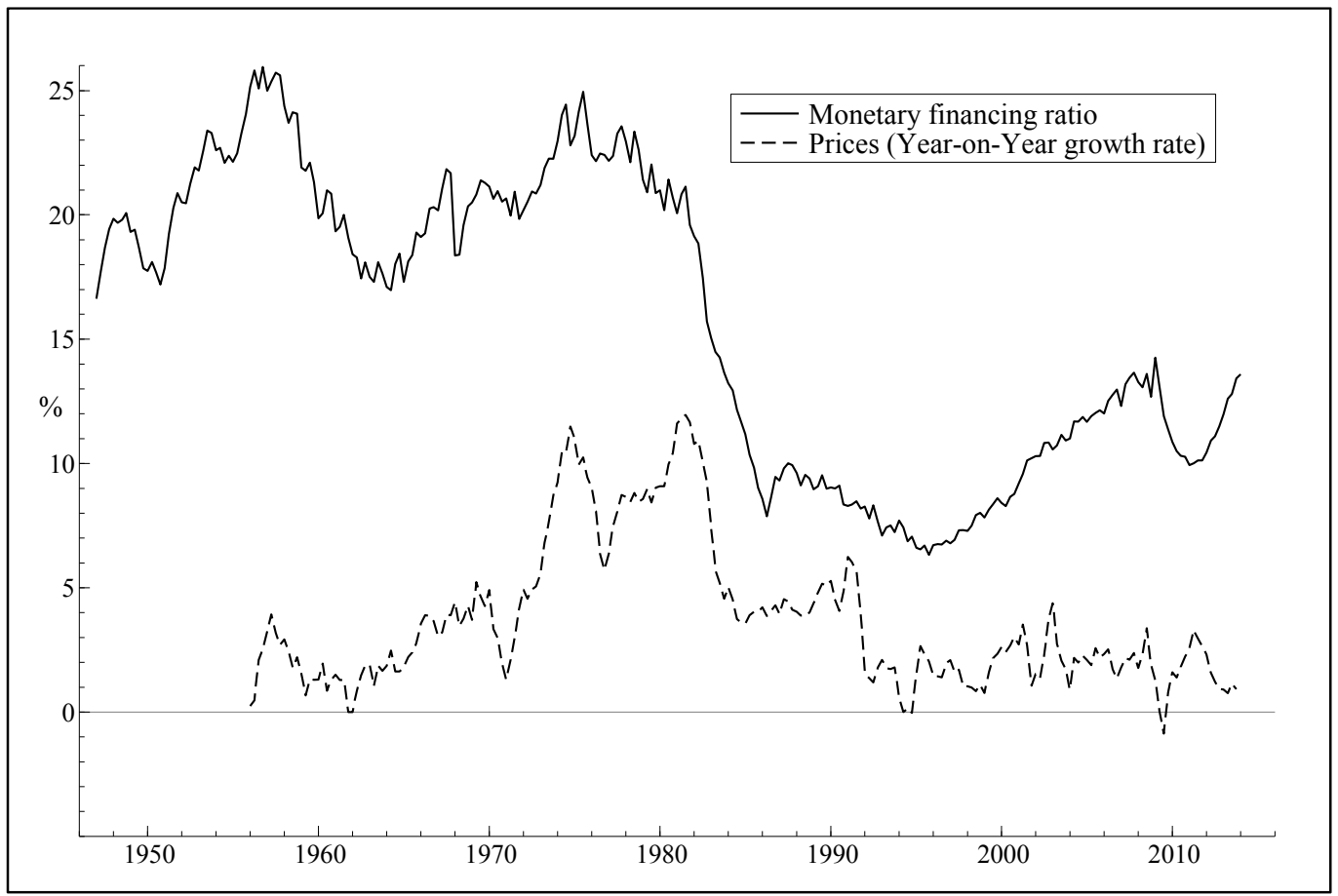

Sources: Monetary financing ratio is the proportion of total public debt held by the Bank of Canada or government from Canadian Statistics, CANSIM Table 176-022; Prices are the YoY growth rate of the Canadian Consumer Price Index (2010=100) from the OECD (2010) MEI.

Here we focus on the monetary financing activities of the Bank of Canada to support: 1) the lifting of Canada out of the Great Depression of the 1930s and the subsequent war mobilization, which involved substantial direct and indirect (via the chartered banks) credit creation to fund government war spending; 2) postwar recovery and industrialization in the 1950s and 1960s, which saw the central bank support government spending through the maintenance of fixed low rates of bond and Treasury bill financing; and 3) the Canadian small business sector, through the Industrial Development Bank (IDB), a wholly owned subsidiary of the Bank created in 1945, which lent directly to small and medium-sized businesses across Canada up until 1975 where it was transferred to government ownership.

\subsection{Historical Origins}

Canada was a late adopter of government-issued money and central banking. Competitive fractional-reserve banking with note-issuing banks and without an indigenous central bank was the norm well in to the twentieth century and proved to be remarkably stable, in contrast to the experience of their southern neighbor, the US. ${ }^{21}$ Rather than the relatively independent unit banks that emerged in the US, Canada developed a national branch bank network with a

\footnotetext{
${ }^{21}$ See Bordo et al. (1996), Gorton and Huang (2002), and Calomiris and Haber (2014) for discussions.
} 
relatively small number of large and diversified commercial banks. ${ }^{22}$ The nationwide branch system also suited the needs of a largely agricultural-and-lumber-based economy, with its requirements for seasonal liquidity and with capital spread widely and thinly across a vast continent (Watts 1972, ch. 1).

The Bank of Canada's creation in 1934 can be viewed as being driven more by domestic political, rather than economic or international, pressures (Bordo and Redish 1987; Cain 1996). ${ }^{23}$ Domestically, there was considerable hostility amongst the Canadian public towards the private banking system, which was held responsible for the deflation experienced during the Great Depression. The Canadian banking system in 1930 was highly concentrated with the three largest banks controlling $75 \%$ of industry deposits. There was evidence of collusion within the industry body, the Chartered Bank Association, to artificially constrain the money supply (Bordo and Redish 1987, 415).

The Bank of Canada Act of 1934, which gave the Bank the sole right to issue bank notes, determined that the function of the newly formed central bank would be:

to regulate credit and currency in the best interests of the economic life of the nation, to control and protect the external value of the national monetary unit and to mitigate by its influence fluctuations in the general level of production, trade, prices and employment. (Bank of Canada 2008 [1934])

The Act also assigns the Bank an exploitative role in providing monetary financing, stating that "The Bank may...

make loans or advances for periods not exceeding six months to the Government of Canada or the government of a province on taking security in readily marketable securities issued or guaranteed by Canada or any province;

(ii) make loans to the Government of Canada or the government of any province, but such loans outstanding at any one time shall not, in the case of the Government of Canada, exceed one-third of the estimated revenue of the Government of Canada for its fiscal year... and such loans shall be repaid before the end of the first

\footnotetext{
${ }^{22}$ There were 40 highly branched banks in Canada between 1870 and 1914 compared to around 18,000 in the US in 1890 (Williamson 1989, 2).

${ }^{23}$ Bordo and Redish (1987) reject the more traditional arguments for the creation of the Bank- that a lender of last resort was required for a competitive banking system or that the Bank was needed to stabilize the economy following the abandonment of the gold standard - and find historical and econometric evidence to support a more political motivation for its inception.
} 
quarter or after the end of the fiscal year of the government that has contracted the loan. ${ }^{24}$

Despite vociferous opposition from the Canadian representatives on the British dominated Macmillan Commission, which helped set up the Bank, and the progressive Liberal Party, the Bank of Canada was initially set up with private shareholders following the Bank of England model; however, shortly afterwards, the Liberal Party won power in the federal election of 1935 and set about nationalizing the Bank. ${ }^{25}$ The Ministry of Finance was given a majority of stock and the board enlarged with government-appointed directors, each of whom had two votes. By 1938, all private holders of stock were forced to sell their shares to the government. In the same year, the first Governor of the Bank, the Canadian Graham Towers asserted the primacy of the state in the conduct of the central bank's monetary policy, which:

...must conform to the policy of their respective governments. No other conception of the situation is possible in this day and age, nor would any other state of affairs be desirable in view of the vital effects which monetary policy can have on the affairs of the country. ${ }^{26}$

The Bank's governance structure ensured a close relationship to the government. The board of directors was appointed for three years by the government whilst the governor and the chair of the board were appointed by the directors with the approval of the government, for a seven-year term depending on good behavior. The Deputy Minister of Finance also sat on the board of directors but without a vote. Under this arrangement it was generally understood that, in case of a serious and basic difference of opinion, a determined government could force the resignation of the governor (Neufeld 1958a, 10-13). This happened only once in 1961 when the government requested the resignation of Governor James Coyne following a breakdown in relations with the Treasury.

\subsection{Early Operations and Recovery from the Great Depression}

The Bank of Canada commenced operations on March 11, 1935 and immediately began to help the Canadian economy out of depression via expansion of the money supply and the maintenance of low interest rates. The Bank pursued a cheap-money policy with Governor Graham Towers strongly rejecting inflationary warnings from monetary conservatives and

\footnotetext{
${ }^{24}$ Bank of Canada Act 2008 [1934], sections 18(i) and (j). Adapted from COMER submission to the Bank of Canada, Amended Claim, March 26, 2015. Available at: www.comer.org

${ }^{25}$ Leader of the party, W.L. Mackenzie King, stated that: “...In no sense should the bank be, or be permitted to become, a banker's bank. It is and ought to be a government bank, the government being representative of the interest of the country as a whole..." (Williamson 1989).

${ }^{26}$ G.F. Towers, in an address to the Montreal Junior Board of Trade, as reported in The Montreal Gazette, March 15,1938 , in Neufield $(1958,11)$.
} 
adopting a stance that appears much closer to the "credit theory of money" discussed in earlier chapters:

....in stimulating business activity the vital matter is not the amount of money in existence, it is the size of people's income, in other words, the size of the national income. This can grow, and does grow, without any definite connection between such growth and a growth in bank deposits or note circulation. (Bank of Canada 1936, 12)

Expansion was initially achieved through direct central bank money creation via advances to the state: $\$ 4$ million was advanced to the government in 1935 in four installments, all of which were eventually repaid. However, the vast bulk of financing was achieved through the Bank's active participation and shaping of the Canadian government bond market.

The Bank conducted four main kinds of activity in this area (Neufeld 1958a, 81-111). First, it undertook direct deficit financing through purchases of government securities from the government; secondly, it pumped large quantities of cash reserves into the chartered banks via bond purchases and maintained a low bank rate to ensure they had sufficient liquidity to further finance the government via direct purchase of securities. This can be seen as a form of indirect monetary financing via private bank monetization of government debt (Watts 1972, 54). Thirdly, via these two operations and the development of a short-term Treasury bills market, the Bank ensured low yields on government bonds throughout the period, thus reducing the cost of deficit-financing; fourth, working with the Department of Finance, it developed illiquid "deposit certificates" - usually with a six-month maturity — that enabled the government to raise short-term finance directly from the chartered banks (Ascah 1999, 108-11).

In the prewar period between 1935 and 1939, the Bank played a major role in Canada's recovery from the Great Depression, funding over two-thirds of government expenditure over these five years. ${ }^{27}$ Nominal gross national product (GNP) expanded by $77 \%$ in contrast to the $70 \%$ contraction in the previous five years, with a sharp increase in capital investment and private expenditure. ${ }^{28}$ Bank deposits expanded by a similar amount, while currency in

\footnotetext{
${ }^{27}$ It purchased a total of $\$ 852$ million of government debt, almost one-third of which was Treasury bills. Government expenditure in the same period was $\$ 2,476$ million. Source: Statistics Canada, Series J55-74: Bank of Canada, assets and liabilities, 1935 to 1977. http://www.statcan.gc.ca/pub/11-516-x/sectionj/4147440-eng.htm\#2; Bank of Canada Review, Series J471-480: Bond and stock yields, annual averages, 1934-1977, table 20.

${ }^{28}$ Downloaded from IMF "Public Finances in Modern History" database — see International Monetary Fund (2013).
} 
circulation increased by $70 \% .{ }^{29}$ Deflation was reversed but inflation remained stable despite the massive expansion in the money supply.

\subsection{Wartime Financing}

During the war, monetary and fiscal policy effectively became one as the Bank of Canada supported the government's efforts to mobilize resources without resistance. With still considerable levels of unemployment and spare productive capacity, the government initially embarked on a policy of "deliberate monetary expansion," mainly via loans from chartered banks (Mcivor 1958, 176). This was enabled by the Bank's controlling role of both chartered private bank cash and more general influence on the banks and the bond market (Mcivor 1958, 176).

The Bank also enabled Canada to nationalize its debt, reducing the non-resident holdings of government debt from one-third of the total to a few percent after negotiations with the British government for the repatriation of Canadian foreign pay securities (Fullerton 1962, 59). A number of large Victory war loans saw a rapid expansion in residential and institutional holdings of government debt, around a quarter of which was monetarily financed via credit creation through an expansion in bank loans to households for such purchases (Neufeld 1958a, 155), ${ }^{30}$ as well as the central bank expanding its purchases. As shown in figure 3, the Bank engineered a long period of “cheap money," with long-term rates staying around $3 \%$ until the late 1950 s and shorter-term rates at less than $1 \%$.

During the war period, $\$ 517.8$ million of securities were bought directly from the government with newly created central bank money and by converting numerous maturing securities into new Government of Canada issues (Neufeld 1958a, 145; Mcivor 1958, 174). As Plumptre (1941, 155-56) remarks, the effect of this increase in note issue was to provide "a sort of interest-free loan to the Government through the medium of the Bank of Canada." The Bank issued the notes at virtually zero cost to itself, whilst the profits paid to it by the government for holding government debt were all paid back to government which owned all of its stock.

\footnotetext{
${ }^{29}$ Statistics Canada, section J, Table J1-10 and J11-20, available online at http://www.statcan.gc.ca/pub/11-516$\mathrm{x} /$ sectionj/4147440-eng.htm\#1

${ }^{30}$ Bank loans for the First Victory War Loan of June 1941 were $\$ 135,978,539$ out of a total subscription of $\$ 730,000,000$, whilst for the Second Victory Loan they were $\$ 209,800$ out of a total subscription of $\$ 845,000,000$ (Kindleberger 1942, 4). Figures for later loans were not available.
} 
Table 1: Federal government funded debt operations during the Second World War (millions of Canadian dollars)

\begin{tabular}{|c|c|c|c|c|c|c|c|}
\hline Fiscal Year (March 31) & 1940 & 1941 & 1942 & 1943 & 1944 & 1945 & 1946 \\
\hline \multicolumn{8}{|l|}{ Borrowing: } \\
\hline $\begin{array}{r}\text { General public war loans } \\
\text { and certificates }\end{array}$ & 200 & 358 & 1659 & 1050 & 2732 & 2948 & 3598 \\
\hline Chartered banks & 200 & 250 & - & 820 & 170 & 112 & - \\
\hline Central bank & 一 & 325 & - & 193 & - & - & 一 \\
\hline Treasury bills & & 75 & 40 & 30 & 60 & 20 & 70 \\
\hline \multicolumn{8}{|l|}{ Loan retirements: } \\
\hline domestic & 100 & 110 & 36 & 42 & 60 & 252 & 761 \\
\hline foreign & 84 & 147 & 180 & 113 & 106 & - & 155 \\
\hline $\begin{array}{l}\text { Total increase in funded } \\
\text { debt }\end{array}$ & 216 & 676 & 1492 & 2121 & 2951 & 3027 & 2823 \\
\hline $\begin{array}{l}\text { Average interest rate } \\
\text { payable on debt }\end{array}$ & 3.4 & 3.06 & 2.9 & 2.6 & 2.55 & 2.51 & 2.49 \\
\hline
\end{tabular}

Sources: Adapted from Mcivor (1958, 174-175); original sources: Dominion of Canada, Public Accounts 1940 1946; Budget Speeches 1940-1946; National War Finance Committee, Statistics and Information on Dominion Government Public Borrowing Operations from September 1939 to December 1945 (Ottawa 1946).

Figure 2: Distribution of Canadian federal government debt (annual), 1938-62

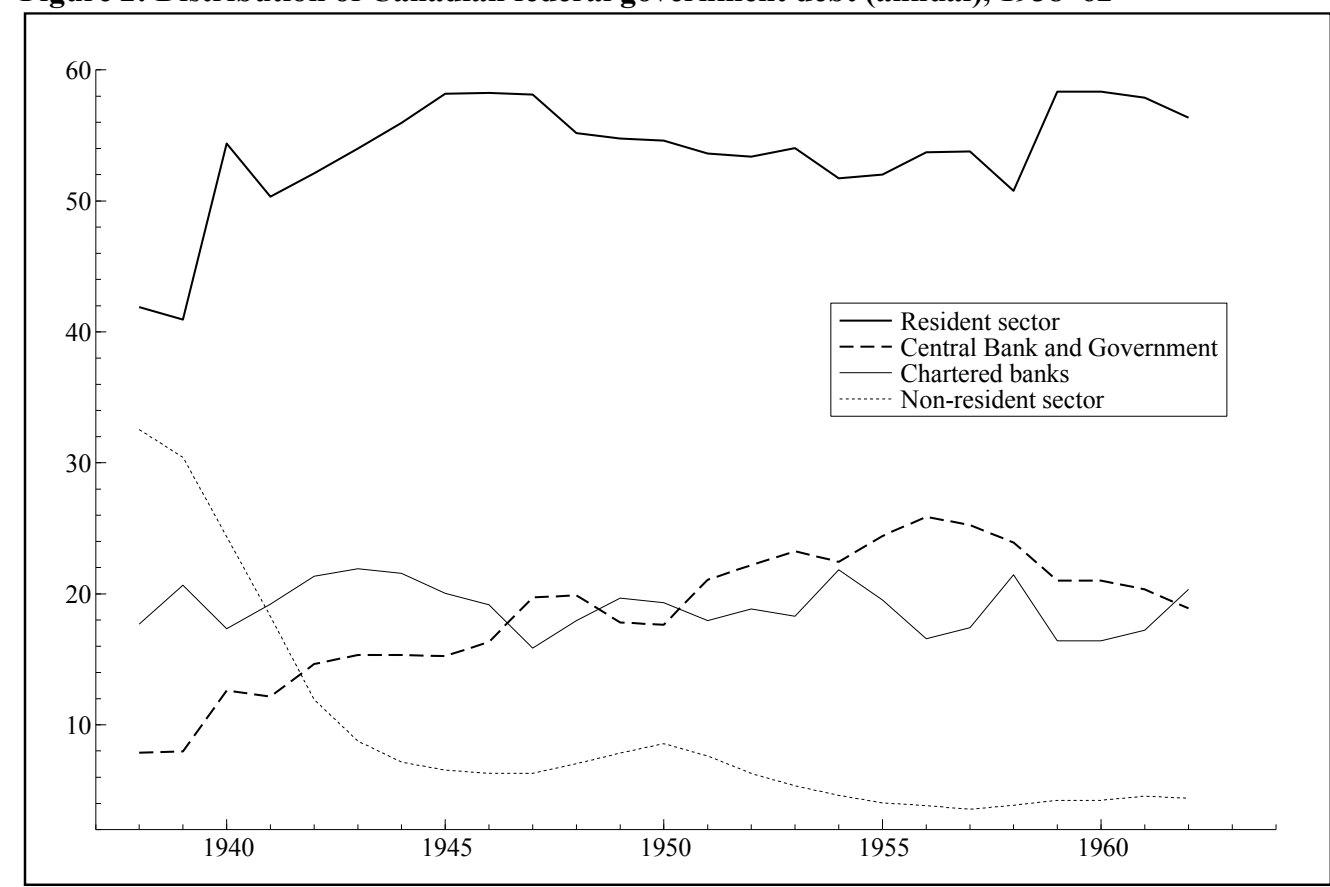

Sources: "Government of Canada Direct and Guaranteed Securities: Annual Distribution of Government debt holdings," Bank of Canada, Statistical Summary, Financial Supplement $(1959,56)$ 


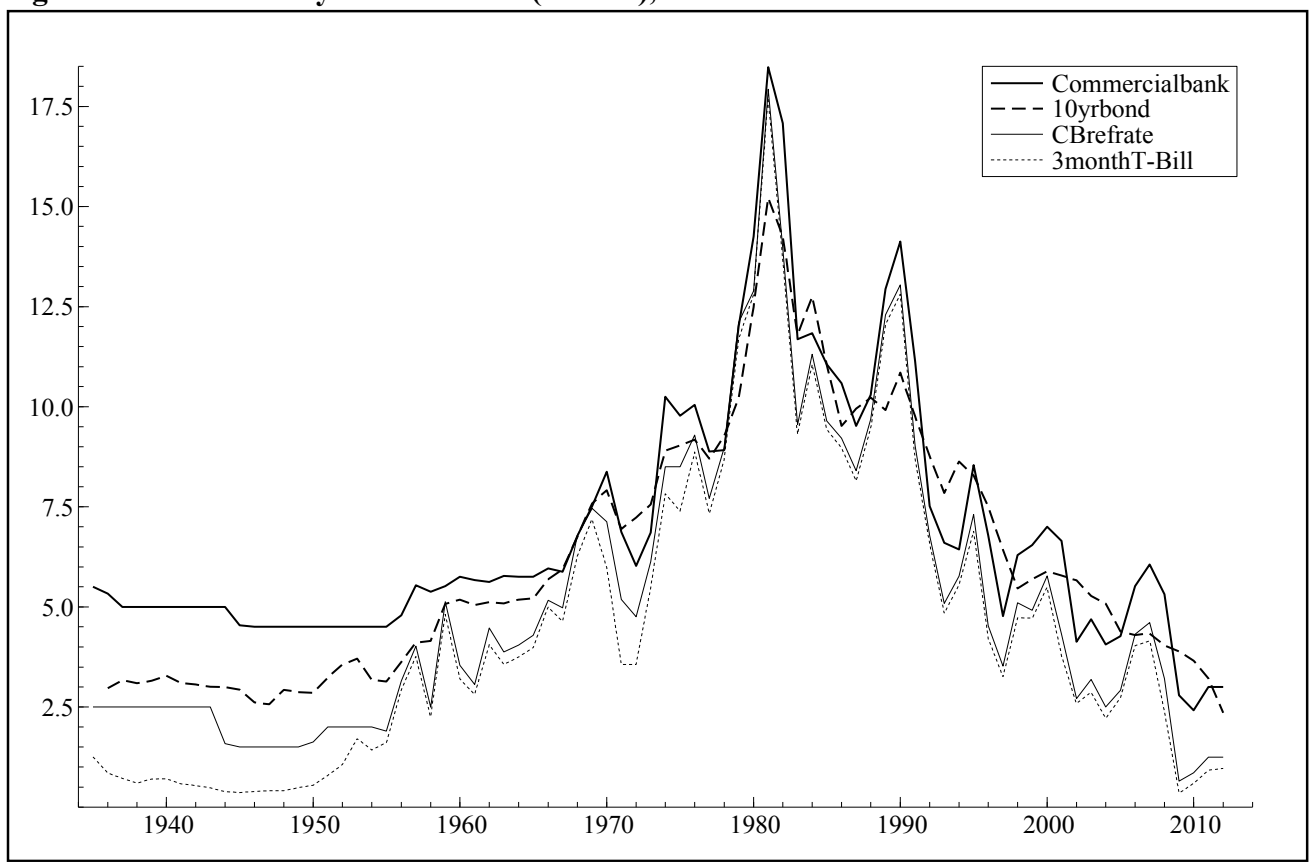

Source: Canadian Statistics, CANSIM Table 176-0043: "Financial market statistics, last Wednesday unless otherwise stated, monthly (percent unless otherwise noted)"

From 1941 to 1943 , the government borrowed \$1,165 million directly from the chartered banks, of which $\$ 715$ million were illiquid deposit certificates issued at three-eighths of $1 \%$ (Neufeld 1958a, 133). ${ }^{31}$ The central bank accommodated such purchases and maintained a low yield on government debt $(2.2 \%)$ by providing the chartered banks with sufficient liquidity to enable them to maintain their preferred cash ratio of $10 \%$ (Neufeld 1958a, 134). This policy continued in 1944 when the government reduced the bank rate and provided the banks with "more reserves than they had ever had before" (Neufeld 1958a, 138). As a result, the chartered banks bought huge quantities of government securities and ensured easy money conditions for the government and general public. ${ }^{32}$

There was little evidence that such wartime spending was inflationary, despite the historical precedents described in section 2.2. The huge increases in the money supply and credit engineered by the Bank were mainly absorbed by a vast expansion in industrial production, which increased by $28 \%$ between 1939 and 1941, matched by a similar increase in employment (Parkinson 1941, 42; Mcivor 1958, 184). As the war went on and as production and employment began to reach near capacity, the government increased taxation or non-

\footnotetext{
${ }^{31}$ The deposit certificates were based on a similar policy instigated by Keynes in the UK to support Britain in the war; see Howson $(1985,252-53)$. As they were non-marketable, they prevented banks from using them to expand their balance sheets by trading them for T-bills or cash (Tily 2007, 205). For a discussion, see Ascah (1999, 10811) who notes the initial resistance of the chartered banks to the low rate of interest they would earn. ${ }^{32}$ See Mcivor (1958,165-201) for a detailed account of the role of the Bank of Canada in financing the war, including statistical tables.
} 
monetized borrowing from the public and reduced borrowing from the banking sector, which was effective in relieving inflationary pressures without any raising of interest rates (Mcivor $1958,184)$.

\subsection{The Postwar Period, 1945-1975}

The White Paper on Employment and Income of 1945 described the Canadian government's immediate postwar fiscal and economic policies (Canadian Parliament 1945). It outlined the government's intention to adopt Keynesian expansionary economic policies to maintain the high level of employment and income that had been reached during the war period. Deficits would be incurred and national debt increased when unemployment threatened, but would be balanced by surpluses in periods of prosperity (Franks 2006 [1945]). Furthermore, the government stated that it "proposes to pursue a monetary policy which will encourage, through low interest rates, the investment of funds in productive capital contributing to employment" (Deutsch 1957, 222). The 15-year period that followed was one of most prosperous in Canadian history, with high growth, the maintenance of full employment, and budgetary surpluses for most of the period.

\subsubsection{The Industrial Development Bank (IDB)}

In terms of business funding, one of the Bank's key postwar innovations was the creation of a subsidiary institution, the national IDB, with a specific remit to support the small and medium-sized enterprise (SME) sector in Canada. The IDB, created in 1944, was one of the first-ever development banks and became one of the largest and most successful (Business Development Bank of Canada 2014). The important role of the central bank and monetary policy in the IDB's creation is made clear in the preamble to the Parliamentary Act which saw the IDB come in force, with the purpose of the bank:

\begin{abstract}
...to promote the economic welfare of Canada by increasing the effectiveness of monetary action through ensuring the availability of credit to industrial enterprises which may reasonably be expected to prove successful if a high level of national income and employment is maintained, by supplementing the activities of other lenders and by providing capital assistance to industry with particular consideration to the financing problems of smaller enterprises. (Canadian Parliament 1945, 383; quoted in Clark 1985, 21)
\end{abstract}

There were concerns in the Canadian parliament that the IDB would create a conflict of interest for the central bank which was also charged with regulating the country's economy. However, the then-Deputy Minister of Finance did not see this as a concern, arguing that the link between the two banks would be beneficial to the central bank. It would have "more 
intimate contact... with the conditions and the problems of small and medium sized industries." Further, "the operations of the IDB will naturally have to dovetail into the country's monetary policy," and a corporate link between the two banks would make this easier (House of Commons 1944, 1441-43; in Clark 1985, 21).

Figure 4: IDB loans and investments as a proportion of total Canadian domestic bank lending to the private non-financial sector, $1954-75$

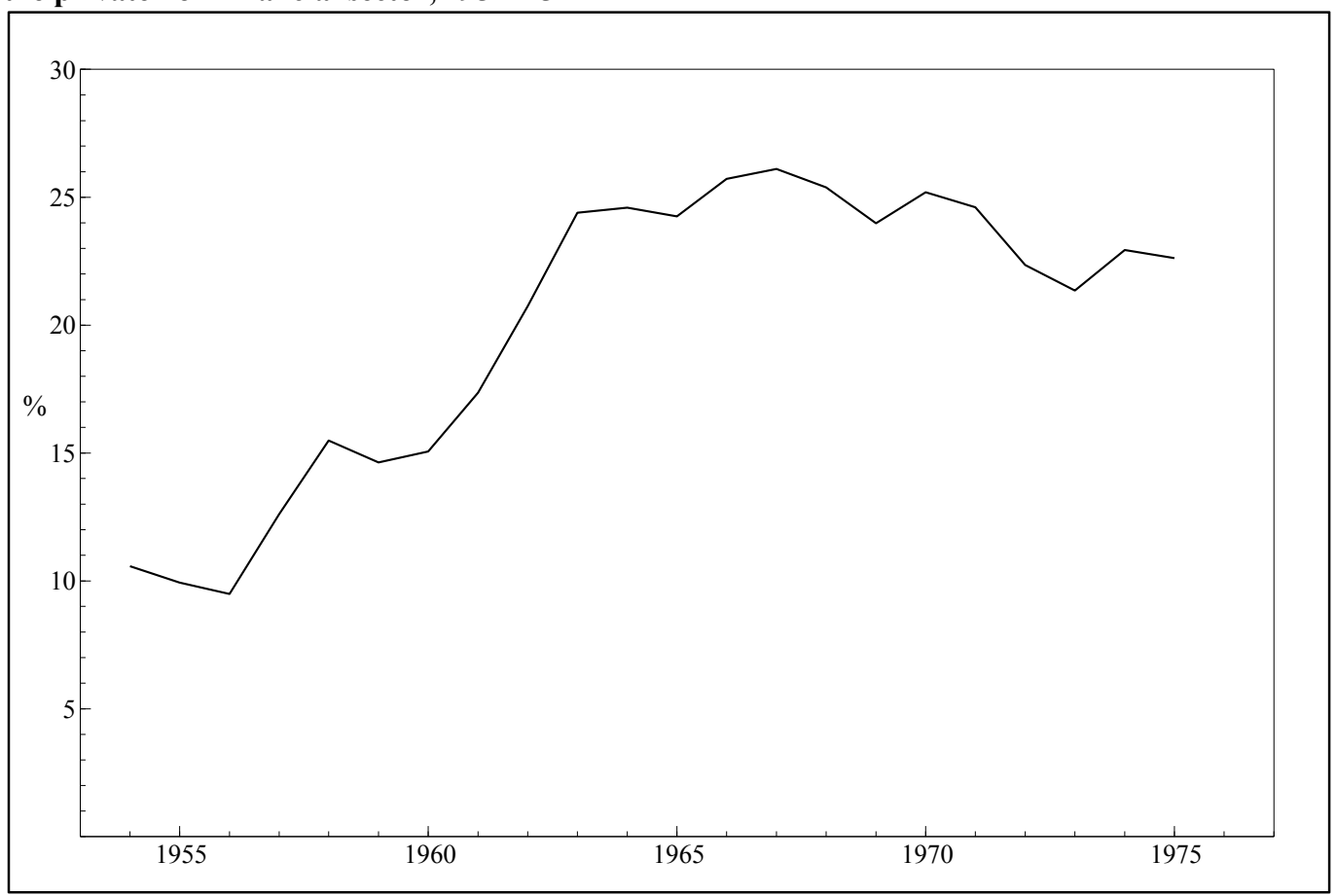

Sources: IDB loans and assets: Clark (1985, 390-91); Domestic Lending to PNFCs: Dembiermont et al. (2013), code Q:CA:B:P:A (adjusted for breaks) and author's calculations.

In its 31 years, the IDB authorized 65,000 loans totaling $\$ 3$ billion for 48,000 businesses (Clark 1985, 7); well over 90\% were successful in establishing themselves and retiring their IDB loans and it was estimated that they employed close to 900,000 people (Clark 1985).

Most of the Bank's borrowers were small with an average loan size of $\$ 47,000$ and $48 \%$ of the loans authorized were for $\$ 25,000$ or less (Clark 1985). The volume of loans made by the IDB stayed relatively stable throughout this period even as economic conditions fluctuated (Clark 1985, 6). The IDB's importance to the commercial sector grew throughout the 1950s and 1960s and during its last ten years the bank provided the equivalent of $25 \%$ of total domestic bank lending to the private non-financial sector (figure 18).

In contrast to most public development banks, which were capitalized with taxpayer funds and leverage-in private finance, the IDB was entirely funded via money creation by the Bank of Canada during its 31-year existence. The IDB was initially funded by the purchase of $\$ 25$ 
million in equity stock by the Bank of Canada. By end of 1947, all \$25 million of stock had been taken down leaving the IDB with significant surplus funds which were invested in government securities. By 1951, virtually all equity funds had been used up in the IDB's loans. It made a number of further sales of bonds to the Bank of Canada to maintain its capital at the same rate as Canadian government three-year bonds.

In the early 1970s, the federal government recommended that the IDB's link with the Bank of Canada be severed and a separate Crown corporation, owned and funded directly by the federal government, be created.

\subsubsection{The Bank's support for government finance and credit controls}

As well as supporting SME financing, the Bank of Canada continued its policy of ensuring easy and cheap finance for government to support fiscal expansion and maintain the policy of full employment. Monetary policy during this period diverges significantly from the NMC and CBI approaches outlined in section 2.3. Rather, it was closer to the "Functional Finance" (Lerner 1943) and "Modern Monetary Theory" schools (Wray 2012) outlined in section 2.4. Changes to the short-term interest rate were generally not seen as a useful policy instrument (Neufeld 1958b) and fiscal policy took on much of the responsibility for dampening the inflationary surges that inevitably followed the war, via increases in taxation and repeated budget surpluses (Deutsch 1957). Although the bank did make use of open market operations, it also employed more direct methods. These included variable secondary reserve requirements, purchase and resale agreements, management of government deposit balances, interest rate agreements between the Bank of Canada and chartered banks, and quantitative credit guidance and moral suasion, both formal and informal (Neufeld 1958a, 75-80; Mcivor 1958, 156-57; Chant and Acheson 1972). Moral suasion was defined by the Bank as: "a wide range of possible initiatives by the central bank designed to enlist the co-operation of commercial banks or of other financial organizations in pursuit of some objective of financial policy" (Bank of Canada 1962, 37).

One particularly interesting example that illustrates the Bank's focus on supporting government finance over other objectives is its role in the introduction of the short-term money market in 1954. Ostensibly, the purpose was to enhance the overall efficiency and flexibility of monetary policy by broadening the public's holdings of government debt or Treasury bills (Wilson 1966, 295). Another interpretation, however, put forward by Acheson and Chant (1973) is that the introduction of the money market was a means for the Bank to further subsidize the cost of government debt by increasing the quantity of short-term government debt held by chartered banks. Such an interpretation helps explain why one year 
after the introduction of the money market, the Bank enforced a $15 \%$ ratio of liquid assets to deposits on a daily average basis for chartered banks. At the same time the Bank encouraged the money market dealers to hold Treasury bills rather than cheaper banker's acceptances as a form of collateral for their day-to-day loans that chartered banks used to maintain their cash positions. Depending as they did on the Bank's lines of credit for their dealings, the money market dealers did just this - at a financial loss to themselves - but the effect was to force the chartered banks to also hold Treasury bills as their main liquid asset rather than relying on cheaper acceptances (Chant and Acheson 1972).

As shown in figure 5, chartered bank holdings of Treasury debt expanded six-fold, whilst the public's holdings of Treasury bills actually declined over the period. Thus short-term government borrowing for this period was largely funded via enforced private bank credit creation rather than from public savings - again a form of "private bank monetization." The policy can also be seen as a tool of monetary policy of course, since the subsidy provided by the banks was equally a cost to them that reduced their profits and thus capital (Neufeld $1958 b, 210)$.

Figure 5: Distribution of holdings of Treasury bills, 1950-70 (\$millions of Canadian dollars)

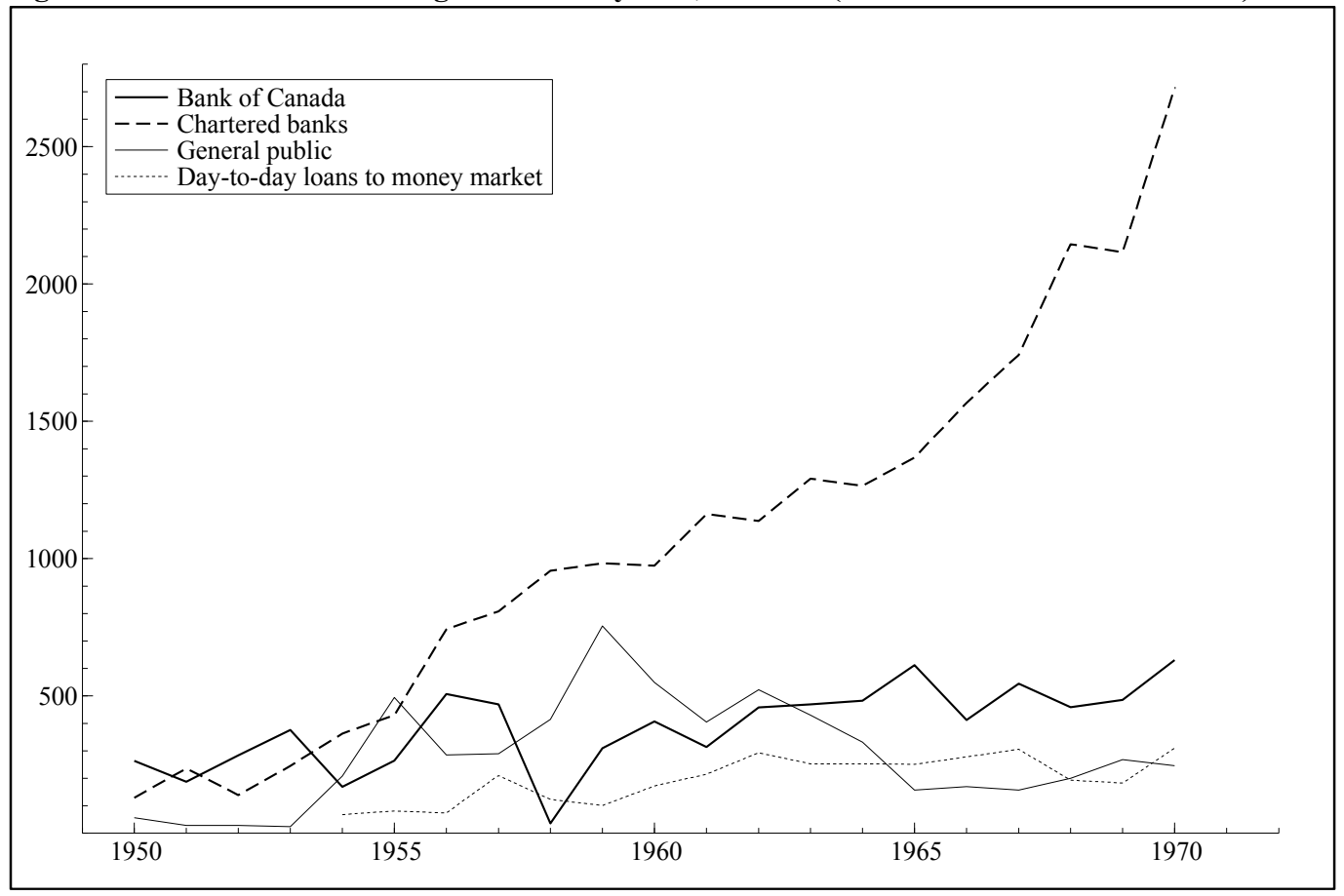

Source: Bank of Canada Statistical Summary Supplement in Acheson and Chant $(1973,648)$

When inflation did threaten Canada, the Bank used quantitative credit controls rather than raising interest rates. Two bouts of serious inflation occurred in the period 1947-53 and can 
be mainly attributed to very large capital inflows from the US generated by investment opportunities in the resource sector and accelerated by the onset of the Korean War (Neufeld 1958a, ch.VI; Bordo and Redish 2006). ${ }^{33}$ In response, in February 1951 the Bank imposed a credit ceiling on all chartered banks which was effective, with deposits stabilizing until the removal of the control in May of 1952 (Mcivor 1958, 220). Reviewing the policy, Mcivor $(1958,219)$ notes that it permitted "declines in long-term bond prices to well below par, without excessive disorganization of the market. With the credit ceiling to prevent the banks from using the additional cash, the Bank could continue to 'cushion' the market by absorbing bonds as required."

More serious domestic inflationary pressures also arose in the late 1950s and led the Bank to impose more restrictive monetary policies in earnest for the first time since the war, raising interest rates and selling securities in to the market along with new liquidity reserve ratios. Such policies continued in to the1960s leading eventually to a crisis with rising unemployment and the resignation of Governor James Coyne in 1961 (Coleman 1991, 721). This in turn led to a collapse of the currency against US dollar and the decision to rejoin the Bretton Woods system in 1962. For the remainder of the 1960s, monetary policy was once again subservient to the full employment agenda of the government and the Bank continued to maintain low interest rates on government debt through its controlling role in the bond market and credit controls.

The low interest rates engineered by the Bank's control of the bond market supported a huge expansion in production in the period 1945-70, with a good part financed by government capital spending which reached around $20 \%$ of total fixed capital investment for most of the 1960s (figure 6). Federal government capital expenditure funded highways, airports, bridges, schools, hospitals, and other physical infrastructure. The rates of growth of both GDP and productivity followed the pattern of public capital formation during this period (Seccareccia 1995) but then began to decline in the late 1960s and 1970s. According to Wylie (1995) the growth of labor productivity in Canadian goods production slowed from an average 5.29\% per annum in $1947-72$, to $1.87 \%$ in $1973-91$, whilst public infrastructure capital accumulation per person-hour worked fell from $5.93 \%$ to $1.21 \%$ per annum. ${ }^{34} \mathrm{~A}$ range of other studies, using alternative production functions, find a positive relationship between the ratio of public capital investment and productivity growth in Canada (Mintz and Preston

\footnotetext{
${ }^{33}$ The Canadian dollar was fixed against the US dollar during the war, and in July 1946 was revalued to parity against the US dollar. In late 1949, Canada joined Britain and a number of other countries in devaluing against the dollar, returning to the wartime rate of 90 cents.

${ }^{34}$ Wylie uses both Cobb-Douglas and translog aggregate production functions and estimates a time series from 1946 to 1991. Infrastructure is postulated to be an input to aggregate goods production, along with traditional direct labor and capital inputs.
} 
1993; Harchaoui and Tarkhani 2003; Paul et al. 2004). Aschauer (1989) found a similar relationship for the US and the relationship has also been found to hold in cross-country studies (Romp and De Haan 2007; Munnell 1992).

Figure 6: Canadian government fixed capital investment measures, 1947-2012

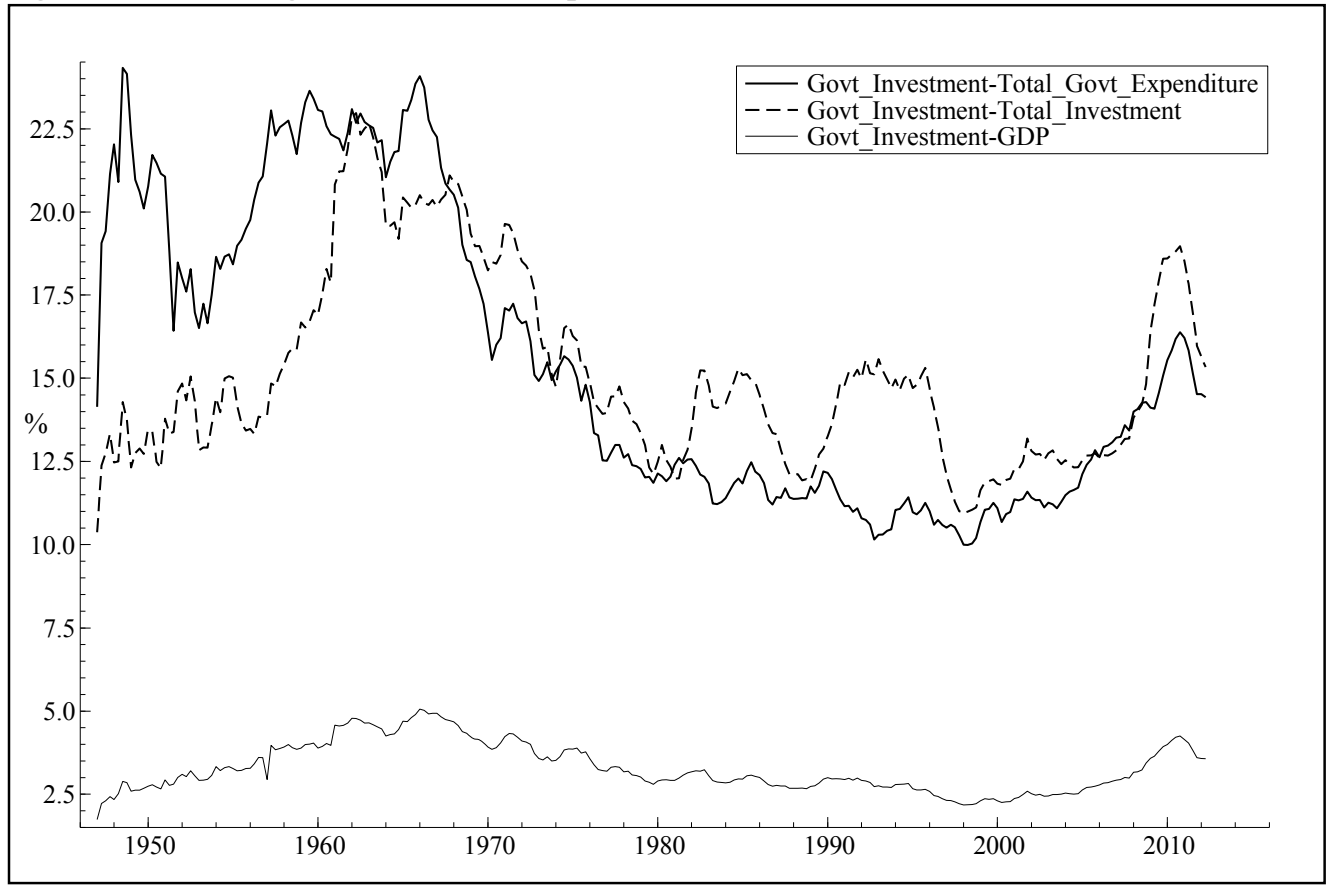

Source: Statistics Canada. Table 380-0002 - GDP, expenditure-based, quarterly (millions of dollars), seasonally adjusted at market prices.

During the period 1960-75, the federal government also introduced virtually all of the major policy innovations that make up Canada's system of social programs: Canada-wide Medicare, universal pensions, the modern unemployment insurance system, and cost-sharing with the provinces for higher education and welfare. Despite this massive expansion in spending, budgets remained roughly balanced. The average federal deficit from 1950 to 1980 was an insignificant $0.3 \%$ of GDP (Stanford 1995, 116). Inflation also remained low and stable, ranging between 2 and 5\% (figure 1).

\subsection{The move towards monetarism and inflation targeting}

By the mid-1970s, however, inflation had become a serious issue (hitting 14\% CPI in 1975). Economists puzzled over the simultaneous rise in unemployment that also occurred. The government imposed wage and price controls and the Bank abandoned its support for government financing via the indirect monetization of debt and related policies. Interest rates were allowed to rise (figure 3) and large quantities of government debt were sold on to the 
market to reduce liquidity as the Bank adopted the monetarist policies of monetary aggregate targeting outlined in section 2.3 (Drainville 1995).

Figure 7: Proportion of public debt held by the central bank and government and interest paid on public debt-to-GDP ratio in Canada, 1920-2012 (annual \%)

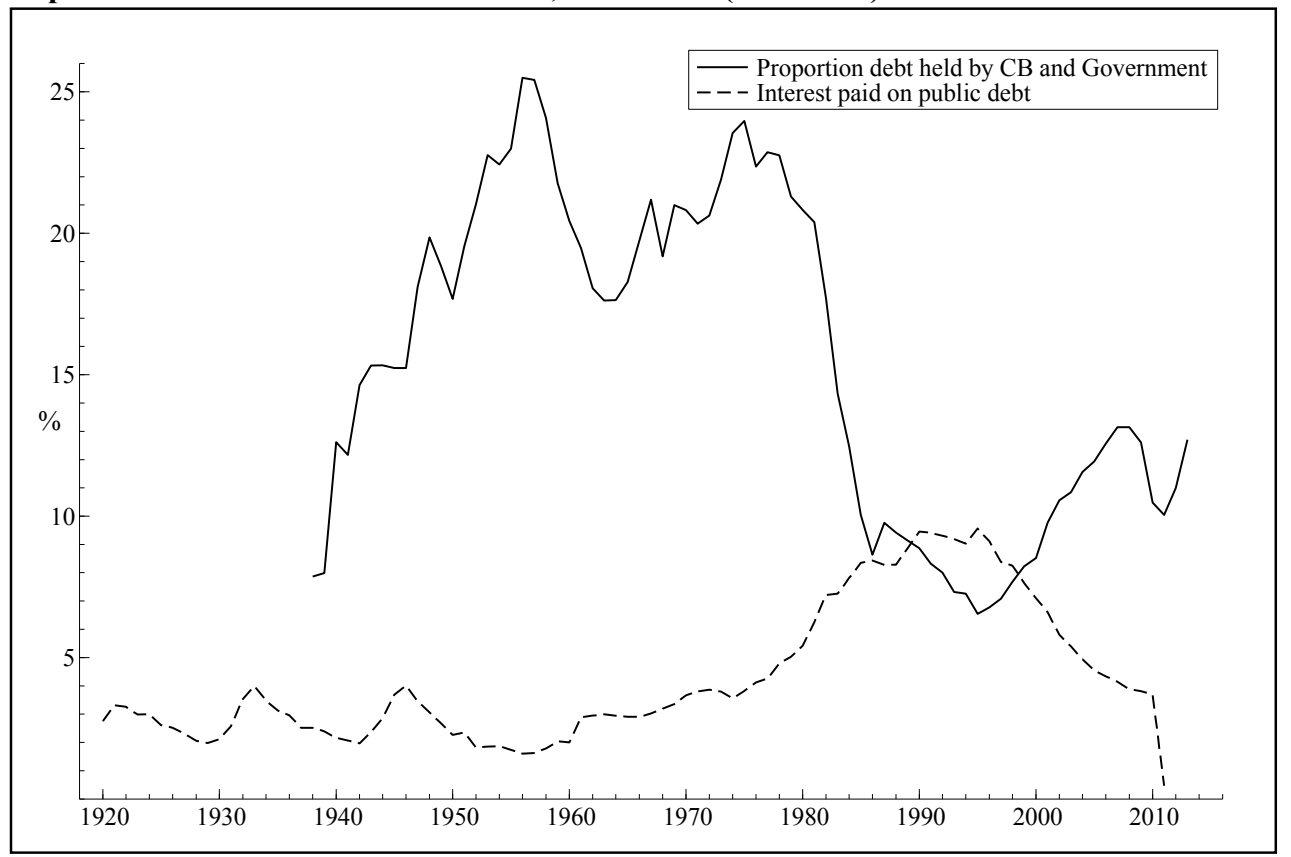

Sources: Interest paid on public debt/GDP from International Monetary Fund (2013); debt held by Bank of Canada and Government 1938-45: "Government of Canada Direct and Guaranteed Securities: Annual Distribution of Government debt holdings," Bank of Canada, Statistical Summary, Financial Supplement (1959, 5); from 19462012, Statistics Canada, Table 176-0022 Government of Canada direct and guaranteed securities and loans, monthly, converted to annual via averaging.

This policy remained in place for close to seven years, despite increasing opposition as interest rates rose to record levels. Accompanying the monetary targeting, the proportion of government debt held by the Bank was reduced from $20 \%$ to $7 \%$ in the space of just three years (figure 8). With double-digit interest rates on long- and short-term government debt (figure 3), this inevitably led to a jump in the proportion of government spending that had to be committed to interest payments that leaked out of the public purse. Rather than such interest payments returning to the government as central bank profits, they were now flowing to the private sector.

The major casualty of this shift appears to have been government capital investment, which, as noted by Seccareccia $(1995,57)$ and as can be seen in figure 8 , collapsed from a peak in the mid-1960s down to levels not seen since the Great Depression years of the 1930s. The 1980s and 1990s saw a more gradual reduction in public expenditure and privatizations but transfer payments actually grew as a proportion of total government expenditure as unemployment rose (figure 8). Federal program spending (excluding interest payments) 
declined, however, as a share of GDP from $18 \%$ in 1975 to just over $15 \%$ by the first half of 1995 (Stanford 1995, 116).

Figure 8: Sectoral distribution of public expenditure (\% of total)

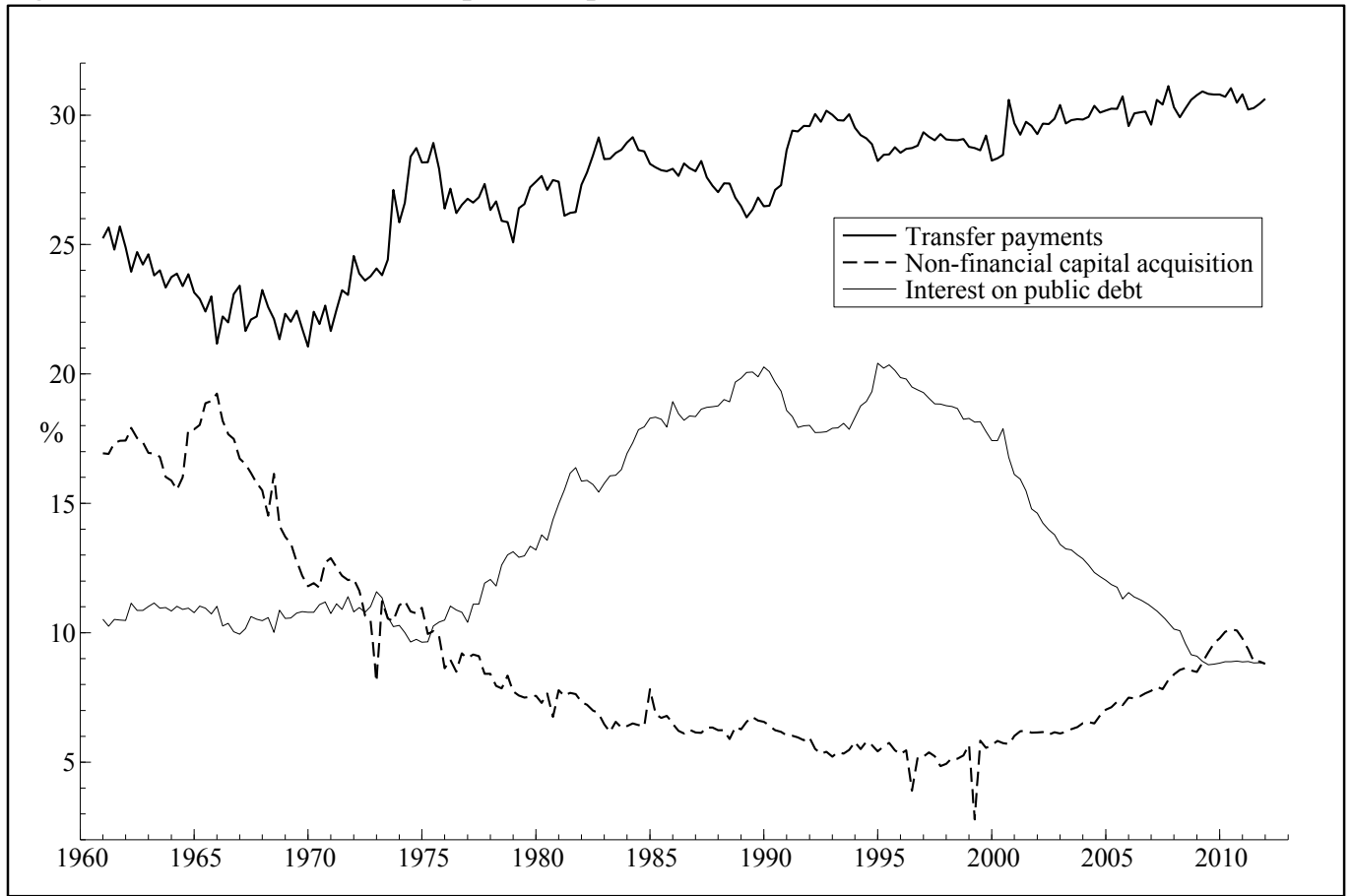

Source: Statistics Canada, National GDP by Income and by Expenditure Accounts -1901, Table 380-0007, "Sector accounts, all levels of government, quarterly." Data is seasonally adjusted at annual rates.

Whatever its effects on government spending, the monetarist experiment was unsuccessful in bringing down inflation. The policy was finally abandoned in November 1982, in the face of a return to double-digit inflation despite a growth rate of M1 that was less than the target rates for most of the period 1975-80. ${ }^{35}$ The Bank officially ended M1 targeting in November 1982 and by 1983, inflation was back under control, despite the lack of an explicit nominal anchor. One explanation is that the Bank piggybacked on the US anti-inflation policies by adopting an implicit exchange rate target with the US dollar (Bordo and Redish 2006, 11) or "exchange rate monetarism" as it has also been called (Chorney and Hansen 1992, 113). As the US raised interest rates, and the US dollar appreciated; Canada followed suit and the result was a negative rate of real money growth (M2), a 4\% decline in real GDP, and a fall in inflation from $12.5 \%$ in 1981 to $5.8 \%$ in 1983 . Indeed, it was not until the late 1980 s that the Bank of Canada turned towards price stability as its overriding policy goal, with inflation having been under control for seven years.

\footnotetext{
${ }^{35}$ Explanations for the 1970s inflationary period in Canada — and other advanced economies—remain contested. A combination of oil shocks, imported US inflation, very high nominal interest rates, and financial innovations that allowed banks to circumscribe existing reserve and liquidity requirements all seem to have played a role (Bordo and Redish 2006, 9).
} 
Beginning in the early 1990s, the Bank began to increase its purchases of government debt (figure 7) via open market operations although this was, officially, part of its new inflation targeting mandate. In comparison to the period 1935-75, however, levels of debt monetization were still considerably lower. Output growth has also been lower across the period and the average unemployment rate has been almost double that of the period 1946$74,4.7 \%$ as against $8.6 \% .^{36}$

\section{EMPIRICAL TEST: DID MONETIZATION OF THE DEBT INFLUENCE INFLATION IN CANADA?}

The qualitative evidence of the case study suggests the Bank of Canada's monetary financing activity did not have inflationary effects, contrary to the NMC/CBI framework. We now conduct an empirical test of this hypothesis by estimating an econometric model of consumerprice inflation in Canada using quarterly observations between 1955 and 2007. If the monetization of debt by the central bank leads to inflation, as proposed by the NMC and CBI policy frameworks, we would expect to find a significant and positive relationship between the two variables over the long run.

\subsection{Empirical Strategy}

Inflation has proved a challenging variable to model and a wide range of different explanations are found in the literature. There are two broad theoretical approaches: first, "cost-push" inflation, generated by labor costs, foreign prices, exchange rates, and interest rates; and secondly "demand-pull" inflation, typically created by excess demands for money, debt, goods, and labor (Vernengo 2006). Empirically, there is evidence that both types of inflation are active. Hendry (2001) for example, finds multiple explanations of inflation in the UK over a 120-year period in a general-to-specific (GETS) model, including the excess demand for goods and services, world price inflation, the short-long interest rate spread, the price mark up, nominal money growth, commodity price inflation, and interest rate changes.

Given these competing theories of inflation, we should be wary of a priori theoretical assumptions and restrictions when estimating an empirical model. Instead the GETS methodology (Hendry 1995; Julia Campos et al. 2005) is adopted. ${ }^{37}$ A general unrestricted

\footnotetext{
${ }^{36}$ Sources: 1946-77: Statistics Canada, Unemployment Series D190-204 and Labour Force Series D463-469, available online at http://www.statcan.gc.ca/pub/11-516-x/index-eng.htm\#U; 1975-2013: OECD, Main Economic Indicators - complete database, Main Economic Indicators (database), http://dx.doi.org/10.1787/data-00052-en [accessed July 29, 2014] OECD descriptor ID: LRUNTTTT

${ }^{37}$ The econometrics software PCGive including the autometrics selection algorithm was used for the econometric modelling.
} 
model (GUM) is first estimated, which embeds the competing theories of inflation as far as data allows. The GUM should be congruent, i.e., statistically valid (see e.g., Bontemps and Mizon 2008). Selection is undertaken on the GUM via valid reductions to a parsimonious form, allowing conditioning of later inferences on the congruent model specification as the best representative of the data generating process. We utilize the "autometrics" search algorithm, which uses a tree-search to detect and eliminate statistically insignificant variables. ${ }^{38}$ To deal with the many shocks and regime shifts over the period, the method of "indicator-saturation" is adopted, following Hendry et al. (2004), which involves adding a dummy variable for each observation and testing for their statistical significance (Doornik 2009). ${ }^{39}$ The single equation GUM will be an autoregressive distributed lag (ARDL) model of the general form:

$$
y t=\sum_{i=1}^{J} \alpha_{i} y_{t-i}+\sum_{k=1}^{N} \sum_{i=0}^{J} \beta_{k i}{ }^{\prime} x_{k, t-i}+\sum_{i=1}^{T} \delta_{i} 1_{\left[t=t_{i}\right]}+\sum_{i=2}^{T} \gamma_{i} S_{\left[t=t_{i}\right]}+\varepsilon_{i}
$$

where $\boldsymbol{x}_{\boldsymbol{t}}=\left(\boldsymbol{x}_{\mathbf{1}, t}, \ldots, \boldsymbol{x}_{\boldsymbol{N}, \boldsymbol{t}}\right)$ is an $(\boldsymbol{N} \times \mathbf{1})$ vector of potential explanatory variables,

$\sum_{i=\mathbf{1}}^{T} \mathbf{1}_{\left[t=t_{i}\right]}$ is a set of saturating indicators defined by $\mathbf{1}_{[t=j]}=\mathbf{1}$ for observation $\boldsymbol{t}=\boldsymbol{j}$, and zero otherwise, and $\sum_{i=2}^{T} S_{\left[t=t_{i}\right]}$ is a set of saturating step dummies defined by $\mathbf{1}_{[t \leq j]}=\mathbf{1}$ for observations up to $\boldsymbol{j}$, and 0 otherwise, $J$ is the maximum lag length and $\boldsymbol{\varepsilon}_{\boldsymbol{t}}$ is a white noise, serially-uncorrelated error term: $\boldsymbol{\varepsilon}_{\boldsymbol{t}} \sim \mathbf{I} \mathbf{N}\left[\mathbf{0}, \boldsymbol{\sigma}_{\boldsymbol{\epsilon}}^{2}\right]$ for $t=1, \ldots, T$.

\subsection{Data}

Data were collected on a wide range of potential explanatory variables on a quarterly basis from $1955 q 1$ to $2007 q 3$, including some archival data that was manually inputted. The dependent variable is the year-on-year (YoY) growth rate of Canadian consumer price inflation (Can_Prices). This is regressed on to nine explanatory variables that encompass the "cost-push" and "demand-pull" literature: US consumer price inflation (US_Price), the Canadian-US dollar exchange rate (US_FX), the monetary base (BaseM), broad money (BroadM), a measure of monetization or public debt outstanding held by the Bank of Canada and the government (Monetiz), total public debt outstanding held by all sectors (Debt), the unemployment rate (Unemp), nominal GDP (Output), and an opportunity cost of money measure or the spread between the bank rate and chartered bank rate ( $R$-Spread). One concern

\footnotetext{
${ }^{38}$ Monte Carlo tests show that GETS selection from the GUM recovers the DGP from large equations with a size and power close to commencing the search from the DGP itself $(2005,845)$

${ }^{39}$ The indicator saturation algorithm in "autometrics" analyses across multiple different combinations of blocks of indicators to find those that are most statistically significant. Under the null that there are no outliers, $\alpha T$ indicators will be retained on average for a significance level $\alpha$, and simulations under the alternative demonstrate a high power for location shifts, even in dynamic models (Hendry and Krolzig 2005)
} 
was collinearity between broad money and base money, but with a pairwise correlation of 0.54 this was judged not to be a major issue (see appendix, table A3).

The time period was limited by the quarterly series on Canadian and US prices and Canadian unemployment, which are only available from 1955q1 and the historical quarterly broad money series that was terminated in 2007. The Canadian Statistics Office has only published quarterly series for many variables going back to 1961 , hence for a number of series, data was inputted manually from physical government publications. ${ }^{40}$

To de-seasonalize and de-trend the data, the fourth difference of the log of the not seasonally adjusted (NSA) nominal level was used (the equivalent of the YoY growth rate). The exceptions are the interest rate measure and the unemployment rate, with the latter seasonally adjusted. Full data sources and construction are shown in table A1 in the appendix and plots of the series are shown in figure 9. It was found that eight lags were required to remove autocorrelation.

Figure 9: Canadian inflation time series' plots

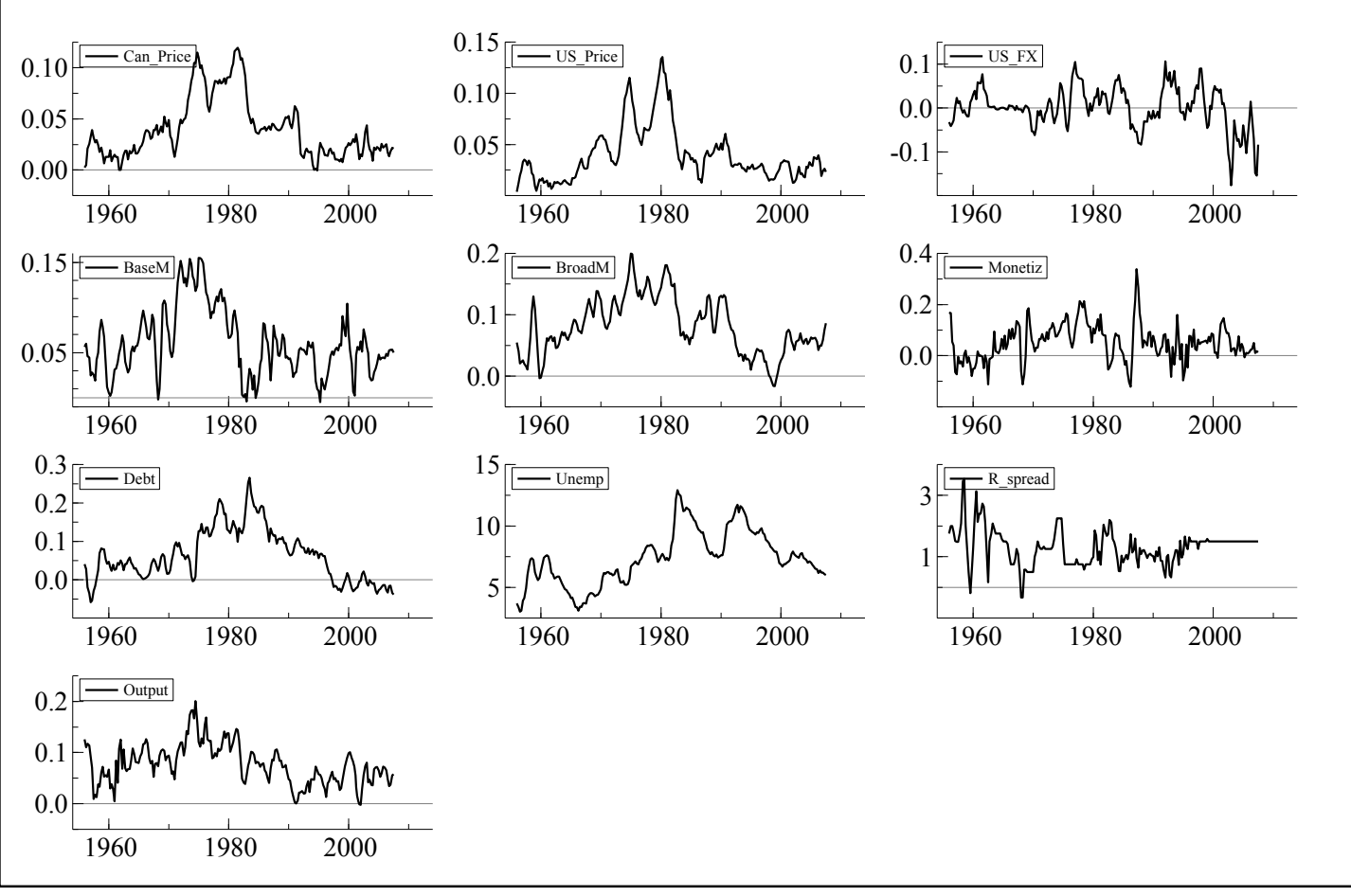

\footnotetext{
${ }^{40}$ These were sourced from the London School of Economics library in the "official statistics" and "central bank statistics" sections.
} 
By including the growth rate of base money and the growth rate of the monetization of the debt and total debt in this model the monetarist and NMC models discussed in sections 2.2 and 2.3 are tested. By including eight lags the intertemporal rational expectations effects that such theories emphasize are allowed for. US prices and exchange rates are used rather than an index of international prices since a range of empirical studies suggest Canada imports significant consumer price inflation from the US, by far its most important trading partner (Cushman and Zha 1997; Johnson 1990).

As is clear from the plots, there is evidence of mean shifts in many of the variables in the early1970s, likely related to the OPEC oil crisis and collapse of Bretton Woods. Unit root tests using the Phillips and Perron (1988) test (reported in the appendix, table A4) suggested the variables were $I(1)$ in the YoY growth rate form, with Monetiz the only variable that appeared to be $I(0)$. Following Hendry's (2001) study of long-term UK inflation, the working assumption used here is that the growth rates series are $I(0)$ with superimposed major breaks, so "appear" to be $I(\mathrm{I})$ series, with measurements having $I(1)$ deviations from the desired theoretical counterparts. This approach is consistent with the effects of revisions on postwar quarterly inflation time series as discussed by Hendry $(1995,14)$. Further differencing in such non-stationary processes may induce non-constancy in derived econometric models, and make it hard to obtain co-integration (Nowak 1991; in Hendry [2001, 256]).

A well-specified GUM was established with the inclusion of just one impulse indicator in 1974q2, coinciding with the 1973 oil crisis, suggesting the conditioning variables and their autoregressive lags were effective in picking up the many other shocks that occurred during the period. Rather than jointly selecting the relevant indicators and step-dummies with the variables, a step- and indicator-saturation is first applied to the GUM with all regressors held unrestricted with eight lags. Selection of the indicators was undertaken at the $1 \%$ significance level.

The general model in levels with YoYGDP as the dependent variable is estimated over 1958q1-2007, and includes eight lags of all conditioning variables, eight lags of the dependent variable, and the 1974q2 indicator. The GUM delivers an equation standard error of $4.3 \%$ and passes all the standard statistical tests relating to autoregressive errors (AR 1-5 test), autoregressive conditional heteroskedasticity (ARCH 1-4), normality, White's tests for heteroskedasticity, Ramsey's reset test for functional form, and the Chow test for a break after 1992q4. Graphical inspection (figure 24) shows a good fit of the scaled residuals (r), residual distribution, and autocorrelation function (ACF), confirming the model is robust. 


\section{Diagnostic testing of GUM for Canadian Inflation}

AR $1-5$ test: $\quad \mathrm{F}(5,103)=1.2143[0.3077]$

ARCH 1-4 test: $\mathrm{F}(4,191)=0.47442[0.7545]$

Normality test: $\chi^{2}(2)=3.3863[0.1839]$

Hetero test: $\quad F(178,19)=1.3640[0.2187]$

Chow test: $\quad F(59,49)=1.3632[0.1330]$ for break after 1992(4)

\section{Figure 10: GUM diagnostic plots and tests}

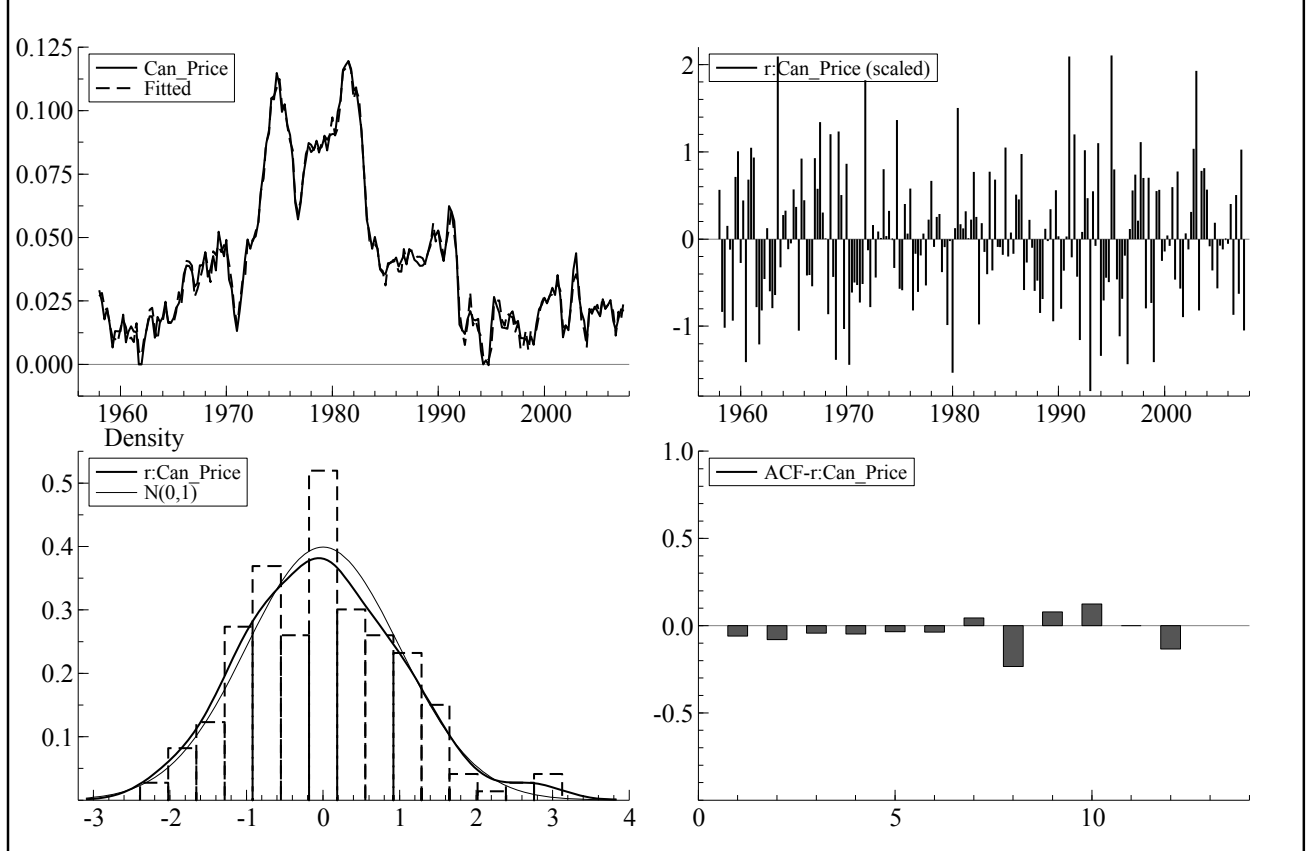

Selection was then applied using PCGive's Autometrics software at a 1\% significance level.

The final selected model is reported below in equation (18), with standard errors in brackets.

The model passes all diagnostic tests described (shown below) at the 5\% level (i.e., congruence is maintained) and the equation standard error is close to that of the GUM at $4.6 \%$ :

Can_Price $=0.93 *$ Can_Price_1 $-0.55^{*}$ Can_Price_4 $+0.56 *$ Can_Price_5

$(0.037)$

$(0.062)$

$(0.081)$

- 0.16*Can_Price_6 $+0.48 * U S$ Urice $-0.4 * U S$ Price_1

$$
\begin{gathered}
+0.11 * \text { US_Price_ } 8-0.055^{*} U S_{-} F X+0.064 * U S_{-} F X_{-} 1+ \\
(0.028) \\
(0.014)
\end{gathered}
$$




$$
\begin{gathered}
0.044 * \text { BroadM_1- } \\
\begin{array}{c}
(0.012) \\
(0.000)
\end{array} \\
0.0024 * \text { Unemp_8 } 8+0.017 * \mathrm{I}: 1974(2)
\end{gathered}
$$

From this parsimonious model a static long-run model can be derived as follows:

$$
\begin{aligned}
\text { Can_Price }= & 0.913722 * U S \_ \text {Price }+0.0412716 * U S \_F X+0.206158 * \text { BroadM } \\
& -0.00173678 * \text { Unemp }+0.0807856 * I: 1974(2) ;
\end{aligned}
$$

As a robustness check, recursive parameter stability tests were carried out and showed the model parameters are relatively stable, with the one-step-ahead sequential Chow tests only exceeding the $1 \%$ bands on four occasions (full results available on request).

\subsection{Interpretation}

In the parsimonious model, the growth rate of monetization, the monetary base, and total public debt drop out suggesting these variables are not correlated with the growth rate of inflation. This result casts doubt on the monetarist and rational choice models described earlier that rising monetization and/or public debt will lead to increases in inflation as agents adjust their portfolios away from money holdings in expectation of inflation and further debt monetization. The robustness of these findings were tested by re-running the GETS selection but this time including all eight lags of the growth rate of monetization in unrestricted form in the GUM and then running exclusion $F$-tests. The exclusion is accepted $(F(9,175)=1.6202$, $p$-value 0.1126 .

The parsimonious model instead suggests a strong cointegrating relationship between US and Canadian inflation. Augmented Dickey-Fuller (ADF) cointegration tests show that the two variables are cointegrated at the $5 \%$ level $(\tau$-statistic: $=3.4257, p$-value 0.03962$) .{ }^{41} \mathrm{In}$ addition, there is also evidence of a positive relationship with the growth rate of the US exchange rate and a negative relationship to the rate of unemployment, as standard theory predicts. The 1974q2 impulse dummy also remains and the inclusion of the eighth lag of both US_Price and Unemp justifies the long lag choice. Whilst the growth rate of central bank

\footnotetext{
${ }^{41}$ ADF cointegration tests use Mackinnon (2010) critical values.
} 
created base money (BaseM) is not statistically significant, the growth rate of broad money (BroadM) does remain in the parsimonious model. As discussed, the majority of this monetary aggregate is created by private banks via credit expansion. Following the "credit theory of money" approach described in section 2.4 , it could be hypothesized that some bank credit creation has been for non-productive activities (e.g., consumption) beyond the productive capacity of the economy independently of the growth of the monetary base.

\section{CONCLUSIONS AND DISCUSSION}

The public and political taboo on monetary financing by government central banks has its roots in long-held fears of war and hyperinflation. Monetarist and rational expectations theories emerged in the 1960s and 1970s which held that "political inflation" due to time inconsistency problems would be inevitable in democracies without strict rules to prevent government deficit monetization. Following the high inflations of the 1970s and 1980s, these theoretical arguments were given policy backing in the form of the move towards CBI in the 1990s, a key element of which was a prohibition of monetary financing.

However, monetary financing, taking various guises, was a relatively standard aspect of economic policy over the past three hundred years. The empirical and theoretical basis for the $\mathrm{CBI} / \mathrm{NMC}$ positions is questionable. Empirical correlation between monetary financing and inflation is, at best, weak and selective, whilst causation has not been demonstrated. The theoretical approach rests on assumptions about the workings of the monetary systemincluding that banks predominantly create money that businesses invest and that central banks can influence such credit creation via changes to short-term interest rates-assumptions that no longer appear to hold.

This paper has presented original historical and empirical evidence to support the policy of monetary financing. The Bank of Canada demonstrated that monetary financing can contribute towards positive and non-inflationary macroeconomic outcomes. The 1935-70 period saw the Canadian economy recover quickly from the Great Depression, weather the Second World War, make a rapid transition from war to peace, and then enjoy a 25 -year period of relatively stable and high growth with rapid industrialization. The period also saw declining public debt, consistent budget surpluses, and full employment. The Bank of Canada played a key supporting role by directly and indirectly financing government debt, controlling government debt markets and domestic credit creation via quantitative controls and "moral suasion." For the majority of the period, the Bank was not independent of the government and its primary objective was full employment and growth rather than price stabilization. Yet 
prices were relatively stable. Our empirical test fully supports the qualitative findings. Of course, the debt monetization of the central bank was not the only explanation for Canada's stable and high growth during the period and further empirical research is required to model its true contribution. However, our finding suggested that when monetization of the debt declined, it was capital investment rather than revenue spending by the government that is reduced with resulting negative impacts on productivity.

Canada is, of course, just one example of debt monetization. An interesting further research avenue would be to examine other countries that used similar techniques to see if Canada's experience was exceptional in some way or whether there are institutional and political economy parallels. There were a number of interesting parallels in other countries during the same period that have received little attention in the literature on monetary policy and macroeconomics. These include the Bank of Japan under former finance minister Korekiyo Takahashi who engaged in direct debt monetization between 1931 and 1934, helping the Japanese economy out of recession and supporting a major expansion in public infrastructure, particularly public works for rural areas (Nakamura 1997, 135-37; Cha 2003). Interestingly, Takahashi appears to have been the inspiration for the current combined QE and fiscal expansion policies of Japanese Prime Minister Abe (Abe 2013; Evans-Prichard 2013), which appear to be an example of implicit debt monetization (Turner 2015). ${ }^{42}$ Another example is New Zealand, where, following its nationalization in 1936, the Reserve Bank of New Zealand (RBNZ) made advances available for the building of state housing, public works activities, and export guarantees, equivalent to almost $20 \%$ of total fixed capital investment and $4 \%$ of GDP $^{43}$ (Sinclair 1976, 157; Hawke 1985).

The topic of monetary financing thus appears a rich one for further empirical and theoretical investigation. That the US\$11 trillion created since the financial crisis via QE programs has not resulted in the desired inflation or growth raises questions about whether this is the most appropriate use of central bank balance sheet expansion. In contrast to the Canadian example, QE has generally involved the purchase of government debt and other financial assets on the secondary markets and been accompanied not by fiscal expansion but fiscal contraction, with Japan the one exception. The Canadian example offers a glimpse of how fiscal and monetary policy can be combined with more direct and positive macroeconomic impacts.

\footnotetext{
${ }^{43}$ New Zealand Long Term Data Series, Series E.3.5 Gross Capital Formation. Available at: http://www.stats.govt.nz/browse_for_stats/economic_indicators/NationalAccounts/long-term-data-series/nationalincome.aspx
} 


\section{APPENDIX}

Table A1: Data sources for econometric model

\begin{tabular}{llll}
\hline Variable & $\begin{array}{l}\text { Description }\left(4^{\text {th }} \text { difference }\right. \\
\text { of the log, NSA, unless } \\
\text { name }\end{array}$ & Source & Code \\
& stated)
\end{tabular}

\begin{tabular}{|c|c|c|c|}
\hline Can_Price & $\begin{array}{l}\text { CPI: All Items for the } \\
\text { Canada, Index } 2010=100\end{array}$ & $\begin{array}{l}\text { OECD (2010) "Main Economic } \\
\text { Indicators - complete database" }\end{array}$ & $\begin{array}{l}\text { OECD: } \\
\text { CANCPIALL } \\
\text { MINMEI }\end{array}$ \\
\hline US_Price & $\begin{array}{l}\text { CPI: All Items for the United } \\
\text { States, Index } 2010=100\end{array}$ & $\begin{array}{l}\text { OECD (2010) "Main Economic } \\
\text { Indicators - complete database" }\end{array}$ & $\begin{array}{l}\text { OECD: } \\
\text { USACPIALL } \\
\text { MINMEI }\end{array}$ \\
\hline$U S \_F X$ & $\begin{array}{l}\text { United States dollar } \\
\text { exchange rate in Canadian } \\
\text { dollars, noon spot rate, } \\
\text { average (dollars) }\end{array}$ & CANSIM: Table 176-0064 & $\begin{array}{l}\text { Bank of } \\
\text { Canada }-7502\end{array}$ \\
\hline BaseM & $\begin{array}{l}\text { Monetary base (notes and } \\
\text { coins in circulation, chartered } \\
\text { bank and other Canadian } \\
\text { Payments Association } \\
\text { members' deposits with the } \\
\text { Bank of Canada) (excluding } \\
\text { required reserves), } \\
\text { monthly average, quarterly } \\
\text { (dollars x } 1,000,000 \text { ) }\end{array}$ & $\begin{array}{l}\text { CANSIM: Table 176-0020: } \\
\text { "Currency outside banks and } \\
\text { chartered bank deposits" }\end{array}$ & $\begin{array}{l}\text { Bank of } \\
\text { Canada }-7502\end{array}$ \\
\hline BroadM & $\begin{array}{l}\text { From } 1947 \text { to } 1967 \mathrm{q} 4 \text { "M2"; } \\
\text { 1968q1-1968q3- } \\
\text { interpolated using cubic } \\
\text { spline filter; } \\
\text { 1968q4-2007q3-“M2 } \\
\text { (NET): Currency outside } \\
\text { banks and chartered bank } \\
\text { deposits," monthly average, } \\
\text { quarterly (dollars x } \\
1,000,000 \text { ) }\end{array}$ & $\begin{array}{l}\text { 1947-1967q4: Metcalf et al. } \\
\text { (1998); } \\
\text { 1968q4-2007q3-CANSIM: } \\
\text { Table 176-0020 }\end{array}$ & \\
\hline Monetiz & $\begin{array}{l}\text { Government of Canada direct } \\
\text { and guaranteed securities and } \\
\text { loans held by Bank of } \\
\text { Canada and Government of } \\
\text { Canada, quarterly (dollars x } \\
1,000,000 \text { ) }\end{array}$ & $\begin{array}{l}\text { CANSIM- Table 176-0022: } \\
\text { "Government of Canada direct } \\
\text { and guaranteed securities and } \\
\text { loans" }\end{array}$ & \\
\hline Debt & $\begin{array}{l}\text { "Distribution of Government } \\
\text { of Canada holdings, total } \\
\text { outstanding" quarterly } \\
\text { (dollars x } 1,000,000)\end{array}$ & $\begin{array}{l}\text { CANSIM - Table 176-0022 } \\
\text { "Government of Canada direct } \\
\text { and guaranteed securities and } \\
\text { loans" }\end{array}$ & \\
\hline
\end{tabular}




\begin{tabular}{|c|c|c|c|}
\hline Unemp & $\begin{array}{l}\text { Unemployment Rate: Aged } \\
15 \text { and Over: All Persons for } \\
\text { Canada, Quarterly, } \\
\text { Seasonally Adjusted }\end{array}$ & $\begin{array}{l}\text { OECD (2010) "Main Economic } \\
\text { Indicators - complete database" }\end{array}$ & $\begin{array}{l}\text { OECD: } \\
\text { LRUNTTTTC } \\
\text { AQ156S }\end{array}$ \\
\hline$R$-Spread & $\begin{array}{l}\text { Spread between bank rate } \\
\text { and Chartered bank } \\
\text { administered interest rates - } \\
\text { prime business. }\end{array}$ & $\begin{array}{l}\text { CANSIM: Table 176-0043: } \\
\text { "Financial market statistics, last } \\
\text { Wednesday unless otherwise } \\
\text { stated, monthly (percent unless } \\
\text { otherwise noted)" }\end{array}$ & $\begin{array}{l}\text { Bank of } \\
\text { Canada }-7502\end{array}$ \\
\hline Output & $\begin{array}{l}\text { Nominal GDP, expenditure } \\
\text { based, quarterly (dollars x } \\
1,000,000 \text { ) }\end{array}$ & $\begin{array}{l}\text { 1947-1961q1: Statistics Canada, } \\
\text { "National Income and } \\
\text { Expenditure Accounts, Vol. 2, } \\
\text { the Quarterly Estimates, 1947- } \\
\text { 1974," Published by the } \\
\text { Minister of Industry (February } \\
\text { 1976), Trade and Commerce } \\
\text { [manually inputted from original } \\
\text { publication, May 2014]. } \\
\text { 1961Q2-2012-2007Q3: } \\
\text { CANSIM Table 380-0002 } \\
\text { "GDP, expenditure-based." }\end{array}$ & $\begin{array}{l}\text { National } \\
\text { Income and } \\
\text { Expenditure } \\
\text { Accounts - } \\
190\end{array}$ \\
\hline
\end{tabular}

Note: OECD Main Economic Indicators available at:

http://stats.oecd.org/Index.aspx?DataSetCode=MEI_FIN; CANSIM (Statistics Canada) tables available at: http://www5. Statcan.gc.ca/cansim/a01?lang=eng

Table A2: Summary statistics - GETS modeling of Canadian inflation

\begin{tabular}{lllll}
\hline Variable & minimum & mean & maximum & std.dev \\
\hline \hline Can_Price & $0-0.00038722$ & 0.039789 & 0.11952 & 0.029519 \\
US_Price & 0.0037383 & 0.039364 & 0.13545 & 0.026846 \\
US_FX & -0.17636 & 0.00034388 & 0.10629 & 0.0474 \\
BaseM & -0.0047147 & 0.060458 & 0.15495 & 0.037155 \\
BroadM & -0.016178 & 0.080965 & 0.19983 & 0.046102 \\
Monetiz & -0.12094 & 0.051667 & 0.33856 & 0.071685 \\
Debt & -0.058453 & 0.062713 & 0.26583 & 0.067883 \\
Unemp & 3.03 & 7.3759 & 12.93 & 2.2183 \\
R_spread & -0.33333 & 1.3046 & 3.5333 & 0.56873 \\
Output & -0.0023841 & 0.076756 & 0.20062 & 0.039029 \\
\hline
\end{tabular}

Notes: $t=207$, time period: $1956(1)-2007(3)$ 
Table A3: Pairwise coefficient correlation matrix-modeling Canadian inflation

\begin{tabular}{|c|c|c|c|c|c|c|c|c|c|c|}
\hline & $\begin{array}{l}\text { Can_ } \\
\text { Price }\end{array}$ & $\begin{array}{l}\text { US } \\
\text { Price }\end{array}$ & $U S \_F X$ & BaseM & BroadM & Monetiz & $\overline{D e b t}$ & Unemp & $\begin{array}{l}R_{-} \\
\text {spread }\end{array}$ & $\begin{array}{l}\text { Out- } \\
\text { put }\end{array}$ \\
\hline $\begin{array}{l}\text { Can_- } \\
\text { Price }\end{array}$ & 1.000 & & & & & & & & & \\
\hline $\begin{array}{l}\text { US } \\
\text { Price }\end{array}$ & 0.875 & 1.000 & & & & & & & & \\
\hline$U S \_F X$ & 0.116 & 0.122 & 1.000 & & & & & & & \\
\hline BaseM & 0.463 & 0.438 & -0.007 & 1.000 & & & & & & \\
\hline BroadM & 0.821 & 0.740 & -0.007 & 0.546 & 1.000 & & & & & \\
\hline Monetiz & 0.383 & 0.373 & -0.013 & 0.515 & 0.426 & 1.000 & & & & \\
\hline Debt & 0.549 & 0.435 & 0.299 & 0.151 & 0.504 & 0.225 & 1.000 & & & \\
\hline Unemp & 0.074 & 0.033 & 0.276 & -0.330 & -0.106 & -0.085 & 0.538 & 1.000 & & \\
\hline $\begin{array}{l}R \\
\text { spread }\end{array}$ & -0.149 & -0.175 & -0.081 & -0.151 & -0.213 & -0.163 & -0.293 & -0.056 & 1.000 & \\
\hline Output & 0.576 & 0.551 & 0.030 & 0.621 & 0.537 & 0.346 & 0.238 & -0.401 & -0.095 & 1.000 \\
\hline
\end{tabular}

Notes: $\mathrm{t}=207$, time period: $1956(1)-2007(3)$ 
Table A4: Unit root tests_-modeling Canadian inflation

PP Z(t) Statistic

Outcome

\begin{tabular}{lllllc} 
Variable & \multicolumn{2}{l}{ YoY growth rate (t=195) } & \multicolumn{4}{l}{$\Delta$ YoY growth rate (t=194) } & \\
& $\begin{array}{l}\text { With } \\
\text { constant }\end{array}$ & $\begin{array}{l}\text { No } \\
\text { constant }\end{array}$ & $\begin{array}{l}\text { With } \\
\text { constant }\end{array}$ & $\begin{array}{l}\text { No } \\
\text { constant }\end{array}$ & \\
\hline \hline Can_Price & -2.166 & -1.148 & -11.093 & -11.119 & $I(1)$ \\
US_Price & -2.542 & -1.300 & -9.181 & -9.203 & $I(1)$ \\
US_FX & -3.935 & -1.300 & -11.495 & -11.530 & $I(0) / I(1)$ \\
BaseM & $-3 . .351$ & -1.708 & -10.787 & -10.816 & $I(0) / I(1)$ \\
BroadM & -2.669 & -1.198 & -8.055 & -8.074 & $I(1)$ \\
Monetiz & -5.756 & -4.607 & -15.114 & -15.151 & $I(0)$ \\
Debt & -1.904 & -1.570 & -10.186 & -10.209 & $I(1)$ \\
Unemp & -2.166 & -0.357 & -7.707 & -7.719 & $I(1)$ \\
R_Spread & -5.046 & -1.787 & -12.558 & -12.596 & $I(0) / I(1)$ \\
Output & -3.851 & -1.833 & -15.140 & -15.175 & $I(0) / I(1)$
\end{tabular}

\begin{tabular}{lccc}
\hline & \multicolumn{3}{c}{ Critical values } \\
& $\mathbf{1 \%}$ & $\mathbf{5 \%}$ & $\mathbf{1 0 \%}$ \\
With const & -3.48 & -2.88 & -2.57 \\
No const & -2.59 & -1.95 & -1.62
\end{tabular}

Notes: Dependent variable = Can-Price; period: 1956q1-2007q3; Observations: 205; Lags for Phillips-Perron (Phillips and Perron 1988) test chosen using Newey-West (Newey and West 1994) automatic bandwidth selector applied by Hobijn, Philip, and Ooms (1998). 


\section{REFERENCES}

Abe, S. (2013), Economic Policy Speech by Mr. Shinzo Abe, Prime Minister of Japan, 19th June 2013 [Online]. Available:

http://japan.kantei.go.jp/96_abe/statement/201306/19guildhall_e.html.

Acemoglu, D., Johnson, S., Querubin, P. and Robinson, J.A. (2008), 'When does policy reform work? The case of central bank independence', NBER Working Paper Series, No. 14033.

Acheson, K. and Chant, J.F. (1973), 'Bureaucratic Theory and the Choice of Central Bank Goals: The Case of the Bank of Canada', Journal of Money, Credit and Banking, Vol. 5, No. 2, pp. 637-655.

Aikman, D., Haldane, A.G. and Nelson, B.D. (2014), 'Curbing the credit cycle', The Economic Journal, Vol. 125, No. 585.

Alesina, A. (1988), 'Macroeconomics and politics', NBER Macroeconomics Annual, Massachussettes: MIT Press, pp. 13-62.

Alesina, A. and Summers, L.H. (1993), 'Central bank independence and macroeconomic performance: some comparative evidence', Journal of Money, Credit and Banking, Vol. 25, No. 2, pp. 151-162.

Arestis, P. and Sawyer, M. (2008), 'A critical reconsideration of the foundations of monetary policy in the new consensus macroeconomics framework', Cambridge Journal of Economics, Vol. 32, No. 5, pp. 761-779.

Ascah, R.L. (1999), Politics and public debt: the Dominion, the banks and Alberta's Social Credit, Alberta: University of Alberta.

Aschauer, D.A. (1989), 'Is public expenditure productive?', Journal of monetary economics, Vol. 23, No. 2, pp. 177-200.

Astle, D. (1997), The Tallies, a Tangled Tale and The Beginning and the Ending : Two Essays, Toronto, Ont.: D. Astle.

B.I.S. (2009), 'Issues in the Governance of Central Banks: A report for the central bank governance group', Basel: Bank for International Settlements.

B.I.S. (2014), '84th Annual Report: 1 April 2013 - 31 March 2014', Basel: Bank of International Settlements.

Bank of Canada (1936), 'First Annual Report', Ottawa: Bank of Canada.

Bank of Canada (1962), 'Submissions by the Bank of Canada to the Royal Commission on Banking and Finance', Ottawa: Canadian Parliament.

Bank of Canada (2008 [1934]), 'Bank of Canada Act, R.S.C., 1985, c. B-2'.

Barnhart, S.W. and Darrat, A.F. (1988), 'Budget deficits, money growth and causality: Further OECD evidence', Journal of International Money and Finance, Vol. 7, No. 2, pp. 231-242.

Barro, R.J. and Gordon, D.B. (1983a), 'A Positive Theory of Monetary Policy in a Natural Rate Model', The Journal of Political Economy, Vol. 91, No. 4, pp. 589-610.

Barro, R.J. and Gordon, D.B. (1983b), 'Rules, discretion and reputation in a model of monetary policy', Journal of monetary economics, Vol. 12, No. 1, pp. 101-121.

Benes, J. and Kumhof, M. (2012), 'The Chicago Plan Revisited', IMF Working Papers, Vol. 12, No. 102.

Bernanke, B.S. (2003), 'Some Thoughts on Monetary Policy in Japan', Paper presented at the Japan Society of Macroeconomics, Tokyo, Japan, May 31st 2003.

Bernanke, B.S. and Mishkin, F.S. (1997), 'Inflation targeting: a new framework for monetary policy?', NBER Working Paper Series, No. 5893.

Bezemer, D., Grydaki, M. and Zhang, L. (2014), 'Is Financial Development Bad for Growth?', Research Institute SOM Research reports, Groningen: University of Groningen, .

Blinder, A.S. (1999), Central banking in theory and practice, Massachussettes: MIT Press.

Bontemps, C. and Mizon, G.E. (2008), 'Encompassing: Concepts and implementation', Oxford Bulletin of Economics and Statistics, Vol. 70, No. s1, pp. 721-750. 
Bordo, M. and Redish, A. (1987), 'Why Did the Bank of Canada Emerge in 1935?', The Journal of Economic History, Vol. 47, No. 02, pp. 405-417.

Bordo, M.D. and Redish, A. (2006), '70 Years of Central Banking: The Bank of Canada in an International Context, 1935-2005', Bank of Canada Review, Vol. 2005, No. Winter, pp. 7-14.

Bordo, M.D., Rockoff, H. and Redish, A. (1996), 'A comparison of the stability and efficiency of the Canadian and American banking systems, 1870-1925', Financial History Review, Vol. 3, No. 01, pp. 49-68.

Bowles, P. and White, G. (1994), 'Central bank independence: A political economy approach', The Journal of Development Studies, Vol. 31, No. 2, pp. 235-264.

Brown, E. (2013), The Public Bank Solution: From Austerity to Prosperity, Baton Rouge: Third Millenium Press.

Business Development Bank of Canada (2014), 'History: 1965-1974', No. May 24 2014, Available: http://www.bdc.ca/EN/about/overview/history/Pages/diversification_years.aspx.

Cagan, P. (1956), 'The Monetary Dynamics of Hyperinflation', IN, Friedman, M. (ed.) Studies in the Quantity Theory of Money, Chicago: University of Chicago Press.

Cain, P.J. (1996), 'Gentlemanly imperialism at work: the Bank of England, Canada, and the sterling area, 1932 - 1961', The Economic History Review, Vol. 49, No. 2, pp. 336357.

Calomiris, C.W. and Haber, S.H. (2014), Fragile By Design: The Political Origins of Banking Crises and Scarce Credit, Princeton: Princeton University Press.

Canadian Parliament (1945), 'White Paper on Employment and income with special reference to the initial period of reconstruction', Federal Reserve Bulletin,, No. June, pp. 536549.

Capie, F., Goodhart, C. and Schnadt, N. (1994), The development of central banking, London: Bank of England.

Capie, F. and Webber, A. (1985), A monetary history of the United Kingdom, 1870-1982. Vol.1, Data, sources, methods, London: Allen \& Unwin.

Cardoso, E.A. (1981), 'Food supply and inflation', Journal of Development Economics, Vol. 8, No. 3, pp. 269-284.

Carpenter, S. and Demiralp, S. (2012), 'Money, reserves, and the transmission of monetary policy: Does the money multiplier exist?', Journal of macroeconomics, Vol. 34, No. 1, pp. 59-75.

Catao, L.a.V. and Terrones, M.E. (2005), 'Fiscal deficits and inflation', Journal of Monetary Economics, Vol. 52, No. 3, pp. 529-554.

Cecchetti, S.G. (2008), 'Measuring the macroeconomic risks posed by asset price booms', IN, John Y. Campbell (ed.) Asset prices and monetary policy, Chicago: University of Chicago Press, pp. 9-43.

Cha, M.S. (2003), 'Did Takahashi Korekiyo rescue Japan from the great depression?', The Journal of Economic History, Vol. 63, No. 01, pp. 127-144.

Chant, J.F. and Acheson, K. (1972), 'The choice of monetary instruments and the theory of bureaucracy', Public Choice, Vol. 12, No. 1, pp. 13-33.

Chick, V. (1996), 'The evolution of the banking system and the theory of saving, investment and interest', IN, Musella, M. and Panico, C. (eds.), Money Supply in the Economic Process: A Post Keynesian Perspective, Cheltenham, UK: Edward Elgar.

Chorney, H. and Hansen, P.B. (1992), Toward a humanist political economy, Ottawa: Black Rose Books.

Clark, E.R. (1985), The IDB: A History of Canada's Industrial Development Bank, Toronto: University of Toronto Press.

Cobham, D. (2012), 'The past, present, and future of central banking', Oxford Review of Economic Policy, Vol. 28, No. 4, pp. 729-749.

Coleman, W.D. (1991), 'Monetary Policy, Accountability and Legitimacy: A Review of the Issues in Canada', Canadian Journal of Political Science, Vol. 24, No. 04, pp. 711734. 
Crowe, C. and Meade, E.E. (2007), 'The evolution of central bank governance around the world', The Journal of Economic Perspectives, Vol. 21, No. 4, pp. 69-90.

Cukierman, A., Web, S.B. and Neyapti, B. (1992), 'Measuring the independence of central banks and its effect on policy outcomes', The World Bank Economic Review, Vol. 6, No. 3, pp. 353-398.

Cushman, D.O. and Zha, T. (1997), 'Identifying monetary policy in a small open economy under flexible exchange rates', Journal of Monetary economics, Vol. 39, No. 3, pp. 433-448.

Davies, G. (2002), History of Money: From Ancient Times to the Present Day, Cardiff: University of Wales Press.

De Haan, J. and Van't Hag, G.J. (1995), 'Variation in central bank independence across countries: some provisional empirical evidence', Public Choice, Vol. 85, No. 3-4, pp. 335-351.

Dembiermont, C., Drehmann, M. and Muksakunratana, S. (2013), 'How Much Does the Private Sector Really Borrow? A New Database for Total Credit to the Private NonFinancial Sector', BIS Quarterly Review, No. March.

Deutsch, J. (1957), 'The Canadian Treasury and monetary policy', The American Economic Review, Vol. 47, No. 2, pp. 220-228.

Doornik, J.A. (2009), 'Autometrics', IN, Castle, J. and Shephard, N. (eds.), The Methodology and Practice of Econometrics: A Festschrift in Honour of David F. Hendry: A Festschrift in Honour of David F. Hendry, Oxford: Oxford University Press, pp. 88122.

Dornbusch, R. (1992), 'Lessons from experiences with high inflation', The World Bank Economic Review, Vol. 6, No. 1, pp. 13-31.

Douglas, P.H., Fisher, I., Graham, F.D., Hamilton, E.J., King, W.I. and Whittlesey, C.R. (1939), 'A Program for Monetary Reform', Colorado State College Working Paper.

Drainville, A.C. (1995), 'Monetarism in Canada and the world economy', Studies in Political Economy, Vol. 46.

Dyson, B. and Jackson, A. (2013), Modernising Money, London: Positive Money.

Edwards, S. and Tabellini, G. (1991), 'Explaining fiscal policies and inflation in developing countries', Journal of International Money and Finance, Vol. 10, pp. S16-S48.

Epstein, G. (2006), 'Central banks as agents of economic development, Research Paper', UNU-WIDER, No. No. 2006/54.

Epstein, G. and Yeldan, E. (2008), 'Inflation targeting, employment creation and economic development: assessing the impacts and policy alternatives', International Review of Applied Economics, Vol. 22, No. 2, pp. 131-144.

Epstein, G.A. (1992), 'Political economy and comparative central banking', Review of Radical Political Economics, Vol. 24, No. 1, pp. 1-30.

Evans-Prichard, A. (2013), 'Abenomics has worked wonders but can it save Japan?', The Telegraph, July 24th 2013.

Ferguson, N., Schaab, A. and Schularick, M. (2014), 'Central Bank balance sheets: Expansion and Reduction since 1900', Paper presented at the ECB Forum on Central Banking, May 2014.

Fisher, I. (1936), '100\% money and the public debt', Economic Forum, No. April-June, pp. 406-420.

Forder, J. (2005), 'Why is central bank independence so widely approved?', Journal of Economic Issues, Vol. 39, No. 4, pp. 843-865.

Franks, C. (2006 [1945]), 'White Paper on Employment and Income', Historica Canada [Online], Available: http://www.thecanadianencyclopedia.com/articles/white-paperon-employment-and-income [Accessed: June 7th 2014].

Frieden, J.A. (2006), Global capitalism: Its fall and rise in the twentieth century, New York: WW Norton.

Friedman, M. (1948), 'A monetary and fiscal framework for economic stability', The American Economic Review, Vol. 38, No. 3, pp. 245-264. 
Friedman, M. (1962), 'Should there be an independent monetary authority?', IN, Yeager, L.B. (ed.) In search of a monetary constitution, Harvard: Harvard University Press, pp. $219-43$.

Friedman, M. (1968), 'The Role of Monetary Policy', The American Economic Review, Vol. 58, No. 1.

Friedman, M. and Schwartz, A. (1963), A monetary history of the United States, 1867-1960, Princeton, N.J.: Princeton University Press.

Fullerton, D.H. (1962), The bond market in Canada, Toronto: Carswell Company.

Goodhart, C. (1988), The evolution of central banks, Mass.: MIT Press.

Goodhart, C. (1998), 'The two concepts of money: implications for the analysis of optimal currency areas', European Journal of Political Economy, Vol. 14, No. 3, pp. 407-432.

Goodhart, C. (2009), 'The continuing muddles of monetary theory: a steadfast refusal to face facts', Economica, Vol. 76, No. s1, pp. 821-830.

Goodman, J.B. (1991), 'The politics of central bank independence', Comparative Politics, pp. 329-349.

Gordon, R.J. (1997), 'The Time-Varying N.A.I.R.U. and its Implications for Economic Policy', The Journal ofEconomic Perspectives, Vol. 11, No. 1, pp. 11-32.

Gorton, G. and Huang, L. (2002), 'Banking panics and the origin of central banking', NBER Working Paper Series, No. 9137.

Graeber, D. (2011), Debt: the first 5,000 years, Brooklyn, N.Y.: Melville House.

Graziani, A. (2003), The monetary theory of production, Cambridge: Cambridge University Press

Grierson, P. (1978), 'The origins of money', Research in economic anthropology, Vol. 1, pp. $1-35$.

Grilli, V., Masciandaro, D. and Tabellini, G. (1991), 'Political and monetary institutions and public financial policies in the industrial countries', Economic policy, Vol. 13, No. 341, p. 92.

Hanke, S.H. and Krus, N. (2012), 'World Hyperinflations', in R. Parker and R. Whaples, (eds.) The Handbook of Major Events in Economic History, London and New York: Routledge.

Hanke, S.H. and Kwok, A.K.F. (2009), 'On the measurement of Zimbabwe's Hyperinflation', Cato Journal, Vol. 29, p. 353.

Harchaoui, T.M. and Tarkhani, F. (2003), Public capital and its contribution to the productivity performance of the Canadian business sector, Ottowa: Statistics Canada.

Hawke, G.R. (1973), Between governments and banks; a history of the Reserve Bank of New Zealand, Wellington,: A. R. Shearer, Govt. printer.

Hawke, G.R. (1985), Depression and recovery in New Zealand, Canberra, Australia: Australian National University.

Hayo, B. (1998), 'Inflation culture, central bank independence and price stability', European Journal of Political Economy, Vol. 14, No. 2, pp. 241-263.

Hendry, D.F. (1995), Dynamic Econometrics, Oxford: Oxford University Press.

Hendry, D.F. (2001), 'Modelling UK inflation, 1875-1991', Journal of applied econometrics, Vol. 16, No. 3, pp. 255-275.

Hendry, D.F., Johansen, S. and Santos, C. (2004), 'Selecting a regression saturated by indicators - unpublished paper', University of Oxford Economics department.

Hendry, D.F. and Krolzig, H.M. (2005), 'The Properties of Automatic GETS Modelling', The Economic Journal, Vol. 115, No. 502, pp. C32-C61.

Hervey, J.L. (1990), 'Changing US trade patterns', Economic Perspectives: Federal Reserve Bank of Chicago.

Higgins, B.H. (1949), Lombard Street in war and reconstruction, New York,: Financial Research Program, National Bureau of Economic Research.

House of Commons (1944), Debates of the House of Commons. Ottowa: Canadian House of Parliament. 
Howells, P. (2006), 'The endogeneity of money: empirical evidence', IN, Arestis, P. and Sawyer, M. (eds.), A Handbook of Alternative Monetary Economics, Cheltenham: Edward Elger, pp. 52-69.

Howson, S. (1985), 'Cheap Money and Debt Management, 1932-51', IN, Cottrell, P.L. and Moggridge, D.E. (eds.), Money and Power: Eassays in Honor of L. S. Pressnell, London: MacMillan.

Hume, M. and Sentance, A. (2009), 'The global credit boom: Challenges for macroeconomics and policy', Journal of International Money and Finance, Vol. 28, No. 8, pp. 14261461.

Humphrey, C. (1985), 'Barter and economic disintegration', Man, Vol. 20, No. 1, pp. 48-72.

Ingham, G.K. (2004), The nature of money, Cambridge, UK: Polity.

Innes, A.M. (1913), 'What is Money', Banking Law Journal, No. May 1913, pp. 377-308.

International Monetary Fund (2013), 'Public finances in modern history', Washington D.C.: IMF.

Investment Watch Blog (2015), 'Since '07, \$11 trillion of global QE', Investment Watch Blog.

Jácome, L.I., Matamoros-Indorf, M., Sharma, M. and Townsend, S.B. (2012), 'Central Bank Credit to the Government: What Can We Learn from International Practices?', IMF Working Papers, Vol. 12, No. 16.

Jevons, W.S. (1875), Money and the mechanism of exchange, London: H.S. King \& Co.

Johnson, D.R. (1990), 'Co-integration, Error Correction, and Purchasing Power Parity between Canada and the United States', Canadian Journal of Economics, Vol. 23, No. 4, pp. 839-55.

Johnson, H.G. (1971), 'The Keynesian revolution and the monetarist counter-revolution', The American Economic Review, Vol. 61, No. 2, pp. 1-14.

Johnston, A. and Pugh, T. (2014), 'The Law and Economics of Quantitative Easing', SSRN Electronic Journal, Vol. 01/2014.

Jordà, Ò., Schularick, M. and Taylor, A.M. (2014), 'The great mortgaging: housing finance, crises, and business cycles', NBER Working Paper Series, No. 20501.

Joyce, M., Miles, D., Scott, A. and Vayanos, D. (2012), 'Quantitative Easing and Unconventional Monetary Policy-an Introduction', The Economic Journal, Vol. 122, No. 564, pp. F271-F288.

Julia Campos, Ericsson, N.R. and Hendry, D.F. (2005), 'General-to-specific Modeling: An Overview and Selected Bibliography', Board of Governors of the Federal Reserve System: International Finance Discussion Papers, No. 838.

Kaldor, N. (1982), The Scourge of Monetarism, Oxford: Oxford Univeristy Press.

Keynes, J.M. (1920), The economic consequences of the peace, London: MacMillan and Co.

Keynes, J.M. (1933), The means to prosperity, London,: Macmillan and co.

Kiguel, M.A. (1989), 'Budget deficits, stability, and the monetary dynamics of hyperinflation', Journal of Money, Credit and Banking, Vol. 21, No. 2, pp. 148-157.

Kindleberger, C.P. (1942), 'Memorandum to Chairman Eccles on the Canadian Government Borrowing Program, 1941-42'. Available at: fraser.stlousifed.org/docs/historical/eccles/039_04_0001.pdf

King, R.G. and Plosser, C.I. (1985), 'Money, deficits, and inflation', Carnegie-Rochester Conference Series on Public Policy, Vol. 22, pp. 147-195.

Klomp, J. and De Haan, J. (2010), 'Inflation and Central Bank Independence: A Meta Regression Analysis', Journal of Economic Surveys, Vol. 24, No. 4, pp. 593-621.

Knapp, G.F. (1905), The State Theory of Money, London: MacMillan.

Kydland, F.E. and Prescott, E.C. (1977), 'Rules rather than discretion: The inconsistency of optimal plans', The Journal of Political Economy, Vol. 85, No. 3, pp. 473-491.

Lerner, A.P. (1943), 'Functional finance and the federal debt', Social research, Vol. 10, No. 1, pp. 38-51.

Lester, R.A. (1938), 'Currency Issues to Overcome Depressions in Pennsylvania, 1723 and 1729', Journal of Political Economy, Vol. 46, No. 3, pp. 324-375.

Levasseur, E. (1894), 'The assignats: A study in the finances of the French Revolution', The Journal of Political Economy, Vol. 2, No. 2, pp. 179-202. 
Lin, H.-Y. and Chu, H.-P. (2013), 'Are fiscal deficits inflationary?', Journal of International Money and Finance, Vol. 32, pp. 214-233.

Lucas, R.E. (1972), 'Expectations and the Neutrality of Money', Journal of economic theory, Vol. 4, No. 2, pp. 103-124.

Mackinnon, J.G. (2010), 'Critical values for cointegration tests', Queen's Economics Department Working Paper No. 1227.

Mann, G. (2010), 'Hobbes' redoubt? Toward a geography of monetary policy', Progress in Human Geography, Vol. 34, No. 5, pp. 601-625.

Mcculley, P. and Poszar, Z. (2013), 'Helicopter Money: or how I stopped worrying and love fiscal-monetary cooperation', Global Society of Fellows, Vol. 7.

Mcivor, R.C. (1958), Canadian monetary, banking, and fiscal development, Toronto,: Macmillan Co. of Canada.

Mckinnon, R.I. (1973), Money and capital in economic development, Washington D.C.,: Brookings Institution Press.

Mcleay, M., Radia, A. and Thomas, R. (2014), 'Money creation in the modern economy', Bank of England Quarterly Bulletin, Vol. 54, No. 1.

Menger, C. (1892), 'On the Origins of Money', The Economic Journal, Vol. 2, No. June, pp. 239-255.

Metcalf, C., Redish, A. and Shearer, R. (1998), 'New Estimates of the Canadian Money Stock, 1871-1967', The Canadian Journal of Economics / Revue canadienne d'Economique, Vol. 31, No. 1, pp. 104-124.

Mian, A. and Sufi, A. (2010), 'The great recession: Lessons from microeconomic data', The American Economic Review, Vol. 100, No. 2, pp. 51-56.

Mintz, J.M. and Preston, R.S. (1993), 'Infrastructure and competitiveness': Industry Canada and the John Deutsch Institute for the Study of Economic Policy, Queen's University.

Moore, B.J. (1988), Horizontalists and verticalists: the macroeconomics of credit money, Cambridge: Cambridge University Press Cambridge.

Muellbauer, J. (2014), 'Combatting Eurozone deflation: QE for the people', VoxEU.org: CEPR.

Munnell, A.H. (1992), 'Policy watch: infrastructure investment and economic growth', The Journal of Economic Perspectives, Vol. 6, No. 4, pp. 189-198.

Nakamura, T. (1997), 'Depression, Recovery and War, 1920-1945', IN, Yamamura, K. (ed.) The Economic Emergence of Modern Japan, Cambridge: Cambridge University Press, pp. 116-158.

Neufeld, E.P. (1958a), Bank of Canada operations and policy, Toronto: University of Toronto Press.

Neufeld, E.P. (1958b), 'The Bank of Canada's approach to central banking', Canadian Journal of Economics and Political Science, Vol. 24, No. 3, pp. 332-344.

Newey, W.K. and West, K.D. (1994), 'Automatic lag selection in covariance matrix estimation', The Review of Economic Studies, Vol. 61, No. 4, pp. 631-653.

Newman, E.P. (1958), 'The successful British counterfeiting of American paper money during the American Revolution', British Numismatic Journal, Vol. 29, pp. 174-87.

Nordhaus, W.D. (1975), 'The political business cycle', Review of economic Studies, Vol. 42, No. 2.

Nowak, E. (1991), 'Discovering hidden cointegration', Economics Working Paper Series: University of California at San Diego.

Parguez, A. and Seccareccia, M. (2000), 'The credit theory of money: the monetary circuit approach', IN, Smithin, J. (ed.) What is money, Oxford: Routledge, pp. 101-23.

Parkinson, J.F. (1941), Canadian war economics, Toronto, Can.,: The University of Toronto Press.

Paul, S., Sahni, B.S. and Biswal, B.P. (2004), 'Public Infrastructure and the Productive Performance of Canadian Manufacturing Industries', Southern Economic Journal, Vol. 70, No. 4.

Phelps, E.S. (1973), 'Inflation in the theory of public finance', The Swedish Journal of Economics, Vol. 75, No. 1, pp. 67-82. 
Phillips, P.C. and Perron, P. (1988), 'Testing for a unit root in time series regression', Biometrika, Vol. 75, No. 2, pp. 335-346.

Phillips, R.J. (1994), The Chicago plan \& new deal banking reform, New York: ME Sharpe.

Pigou, A.C. (1941), 'Types of War Inflation', The Economic Journal, Vol. 51, No. 204, pp. 439-448.

Pilkington, P.C. (2014), 'Endogenous Money and the Natural Rate of Interest: The Reemergence of Liquidity Preference and Animal Spirits in the Post-Keynesian Theory of Capital Markets', Levy Economics Institute, Working Papers Series, No. 817.

Plumptre, A.F.W.W. (1941), Mobilizing Canada's resources for war, London: MacMillan.

Posen, A. (1998), 'Central bank independence and disinflationary credibility: a missing link?', Oxford Economic Papers, Vol. 50, No. 3, pp. 335-359.

Posen, A.S. (1995), 'Declarations are not enough: financial sector sources of central bank independence', IN, Bernanke, B.S. and Rotemburg, J.J. (eds.), NBER

Macroeconomics Annual 1995, Volume 10, Massachussettes: MIT Press, pp. 253274.

Protopapadakis, A.A. and Siegel, J.J. (1987), 'Are money growth and inflation related to government deficits? Evidence from ten industrialized economies', Journal of International Money and Finance, Vol. 6, No. 1, pp. 31-48.

Reichlin, L., Turner, A. and Woodford, M. (2013), 'Helicopter money as a policy option', VoxEU.org, August 21. Available at: http://blogs.reuters.com/felixsalmon/2012/09/03/why-you-wont-find-hyperinflation-in-democracies/

Reinhart, C.M. and Sbrancia, M.B. (2011), 'The liquidation of government debt', NBER Working Paper Series, No. 16893.

Reinhart, M.C. and Rogoff, M.K. (2013), 'Financial and sovereign debt crises: Some lessons learned and those forgotten', IMF Working Papers, Vol. 13, No. 226.

Richards, R.D. (1929), The early history of banking in England, London: P.S. King \& son, Ltd.

Romp, W. and De Haan, J. (2007), 'Public capital and economic growth: A critical survey', Perspektiven der Wirtschaftspolitik, Vol. 8, No. S1, pp. 6-52.

Ryan-Collins, J., Greenham, T., Werner, R. and Jackson, A. (2011), Where does money come from?: a guide to the UK monetary and banking system, London: New Economics Foundation.

Sachs, J.D. (1986), 'The Bolivian hyperinflation and stabilization', NBER Working Paper Series, No. 2073.

Salmon, F. (2012), 'Why you won't find hyperinflation in democracies', Reuters, London.

Sargent, T.J. and Wallace, N. (1975), "'Rational" Expectations, the Optimal Monetary Instrument, and the Optimal Money Supply Rule', The Journal of Political Economy, Vol. 83, No. 2, pp. 241-254.

Sargent, T.J. and Wallace, N. (1981), 'Some unpleasant monetarist arithmetic', Federal reserve bank of Minneapolis Quarterly Review, Vol. 5, No. 3, pp. 1-17.

Sbrancia, M.B. (2011), 'Debt, Inflation, and the Liquidation Effect', Preliminary draft, August 6. Maryland: University of Maryland.

Schacht, H.H.G. and Butler, R. (1927), The stabilization of the mark, New York: Adelphi.

Schularick, M. and Taylor, A.M. (2009), 'Credit Booms Gone Bust', NBER Working Paper Series, No. 15512.

Seccareccia, M. (1995), 'Keynesianism and public investment: a left-Keynesian perspective on the role of government expenditures and debt', Studies in Political Economy, Vol. 46, No. Spring.

Seccareccia, M. and Sood, A. (2000), 'Government Debt Monetization and Inflation: A Somewhat Jaundiced View', IN, Bougraine, H. (ed.) The Economics of Public Spending: Debts, Deficits and Economic Performance, Cheltenham, UK: Edward Elgar, pp. 98-121.

Shaw, E.S. (1973), Financial deepening in economic development, New York: Oxford University Press. 
Simons, H.C. (1951 [1948]), Economic policy for a free society, Chicago: University of Chicago Press.

Sinclair, K. (1976), Walter Nash, Auckland: Auckland University Press.

Stanford, J. (1995), 'The economics of debt and the remaking of Canada', Studies in Political Economy, Vol. 48, No. Autumn, pp. 113-135.

Stein, J.C. (2013), 'Overheating in credit markets: origins, measurement, and policy responses', Speech at the Federal Reserve Bank of St Louis conference: 'Restoring Household Financial Stability after the Great Recession: Why Household Balance Sheets Matter', St. Louis, February 17th, 2013.

Summers, L. (2013), 'Speech', IMF Fourteenth Annual Research Conference in Honor of Stanley Fischer, Washington D.C.,November 8th 2013.

Thiessen, G. (2001), 'Can a bank change? The evolution of monetary policy at the Bank of Canada 1935-2000', Bank of Canada Review, Vol. 4, pp. 35-46.

Tily, G. (2007), Keynes betrayed: Keynes's General theory, the rate of interest and Keynesian economics, New York: Palgrave Macmillan.

Tobin, J. (1981), 'The monetarist counter-revolution today-an appraisal', The Economic Journal, Vol. 91, No. 361, pp. 29-42.

Turner, A. (2013), 'Debt, Money, and Mephistopheles: How Do We Get Out of this Mess?', Cass Business School Annual Lecture, London, 6th February 2013.

Turner, A. (2014), 'Rethinking the monetization taboo', Project Syndicate [Online], No. March 18th 2014, Available: http://www.project-syndicate.org/commentary/adairturner-says-that-some-central-banks--particularly-japan-s--will-never-shrink-theirbalance-sheets.

Turner, A. (2015), 'Japan's Accounting Problem', Project Syndicate [Online], Available: http://www.project-syndicate.org/commentary/japan-monetization-government-debtby-adair-turner-2015-03.

Vernengo, M. (2006), 'Money and inflation', IN, Arestis, P. and Sawyer, M. (eds.), $A$ handbook of monetary economics, Cheltenham: Edward Elgar, pp. 471-489.

Walsh, C.E. (1995), 'Optimal contracts for central bankers', The American Economic Review, Vol. 85, No. 1, pp. 150-167.

Watts, G. (1972), 'The origins and background of central banking in Canada', Bank of Canada Review, Vol. 14, p. 27.

Werner, R.A. (1997), 'Towards a New Monetary Paradigm: a Quantity Theorem of Disaggregated Credit, with Evidence from Japan', Kredit und Kapital, Vol. 30, No. 2, pp. 276-309.

Werner, R.A. (2003), Princes of the Yen: Japan's Central Bankers and the Transformation of the Economy, New York: ME Sharpe.

Werner, R.A. (2005), New paradigm in macroeconomics : solving the riddle of Japanese macroeconomic performance, Houndmills, Basingstoke: Palgrave Macmillan.

Whittington, L. (2015), 'Rocco Galati in court to challenge how Bank of Canada does business', The Star, March 23rd 2015.

Wicksell, K. (1936 [1898]), Interest and prices: A study of the causes of regulating the value of money, New York: Sentry Press.

Williamson, S.D. (1989), 'Bank Failures, Financial Restrictions, and Aggregate Fluctuations: Canada and the United States, 1870-1913', Federal Reserve Bank of Minneapolis Quarterly Review, Vol. 13, No. 3.

Wilson, J.S.G. (1966), Monetary policy and the development of money markets, London: Allen and Unwin.

Wolf, M. (2013), 'The case for helicopter money', The Financial Times, February 12.

Woodford, M. (1995), 'Price-level determinacy without control of a monetary aggregate', Carnegie-Rochester Conference Series on Public Policy, Vol. 43, pp. 1-46.

Wray, L.R. (1998), Understanding modern money, Cheltenham: Edward Elger.

Wray, L.R. (2007), 'A Post Keynesian view of central bank independence, policy targets, and the rules versus discretion debate', Journal of Post Keynesian Economics, Vol. 30, No. 1, pp. 119-141. 
Wray, L.R. (2012), Modern money theory: A primer on macroeconomics for sovereign monetary systems, Hampshire: Palgrave Macmillan.

Wylie, P. (1995), 'Infrastructure and Canadian economic growth', Canadian Business Economics, Vol. 3, No. 2.

Zarlenga, S. (2004), 'The lost science of money', European Business Review, Vol. 16, No. 5. 